Notre Dame Law School

NDLScholarship

Journal Articles

Publications

$3-1-2015$

\title{
The Clerks of the Four Horsemen (Part II, George Sutherland and Pierce Butler)
}

Barry Cushman

Notre Dame Law School, bcushman@nd.edu

Follow this and additional works at: https://scholarship.law.nd.edu/law_faculty_scholarship Part of the Legal Profession Commons

\section{Recommended Citation}

Barry Cushman, The Clerks of the Four Horsemen (Part II, George Sutherland and Pierce Butler), 40 J. Sup. Ct. Hist. 55 (2015). Available at: https://scholarship.law.nd.edu/law_faculty_scholarship/1138

This Article is brought to you for free and open access by the Publications at NDLScholarship. It has been accepted for inclusion in Journal Articles by an authorized administrator of NDLScholarship. For more information, please contact lawdr@nd.edu. 


\title{
The Clerks of the Four Horsemen (Part II, George Sutherland and Pierce Butler)
}

\author{
BARRY CUSHMAN
}

This is the second part of a two-part article. Please see volume 39, no. 3, pages 368-424 for the Introduction and Part I, discussing the clerks to James C. McReynolds and Willis Van Devanter.

\section{The Sutherland Clerks}

Justice Sutherland served from 1922 to 1938 , but during that time he had only four clerks. The first, whom he inherited from his predecessor in office, was a career civil servant. The others were all graduates of George Washington University's Law School, and went on to enjoy interesting and highly successful careers in private practice.

Samuel Edward Widdifield was an 1898 graduate of the Detroit College of Law who clerked for Sutherland during the 1922 and 1923 Terms. ${ }^{1}$ Widdifield might be characterized as a career or serial clerk: he clerked for four different Justices. Born in Uxbridge,
Ontario, Widdifield moved to Michigan as a young boy in 1880 and was naturalized in Detroit in 1896 . He was admitted to practice in Michigan in 1898, and in Massachusetts in 1904. Early in his career, Widdifield handled collections in the office of a Detroit lawyer and practiced with the Traverse City, Michigan firm of Gilbert \& Widdifield. He then moved to Pittsfield, Massachusetts, where he was secretary and law assistant to the president of the Stanley Electrical Company. ${ }^{2}$ He first came to the Court in 1904 at the age of twenty-nine to clerk for Justice Rufus Peckham. After Peckham's death in 1909, Widdifield clerked for Justice Joseph Rucker Lamar during the 1910 and 1911 Terms. ${ }^{3}$ Following his clerkship with Justice Lamar, Widdifield engaged briefly in private practice in Lansing, Michigan before returning to Washington to serve as a secretary to Senator James P. Clarke of Arkansas and as a messenger to the Senate Commerce Committee from 1913 to $1916 .{ }^{4}$ He then returned to the Court to clerk for Justice John Hessin Clarke, 
and, upon Clarke's resignation in 1922, Widdifield moved to the chambers of Clarke's successor, Justice Sutherland. ${ }^{5}$ After two years with Sutherland, Widdifield left to serve for more than five years as assistant counsel to the German Mixed Claims Commission in the State Department. In 1930 he operated his own real estate business in North Beach Maryland, where he served as mayor. From December of 1930 to August of 1931 he worked as an assistant clerk to the House Judiciary Committee. Widdifield then returned to the Court as assistant clerk, a position that he held for eighteen years until his retirement in $1949 .{ }^{6}$ In 1937 he sought to return to the position of law clerk, unsuccessfully applying for a position with the incoming Justice Hugo Black. ${ }^{7} \mathrm{He}$ died in 1960 at the age of eighty-five, a widower survived by two children, six grandchildren, and one great-grandchild. ${ }^{8}$

Alan E. Gray clerked for Sutherland from the 1924 term through the 1930 term. ${ }^{9}$ Gray may have been the most colorful of the Sutherland clerks. His father was a Scottish immigrant who came to Minnesota at a young age and settled in Grafton, North Dakota in 1891. ${ }^{10}$ Alan was born in 1899 , took his B.A. from the University of North Dakota in 1921, and received his law degree from George Washington University in $1924 .^{11}$ That year he married fellow Graftonite Grace Lunding Hope, and the couple moved to Chevy Chase, Maryland. ${ }^{12}$ Following his clerkship with Sutherland, Gray remained for several years in Washington, ${ }^{13}$ where he engaged in a law practice focused on tax matters. ${ }^{14}$ By 1938 , the Grays had moved to Southern California, where they divorced by 1948. Gray quickly married Joan Kettering in 1949 , but was as quickly divorced from her the following year. He then married Jan Hanson Fisher, who left him a widower. In 1967 he married his old Grafton schoolmate Helen Tombs, to whom he remained married until his death. ${ }^{15}$

Gray practiced in Southern California for the balance of his career. ${ }^{16} \mathrm{He}$ continued to specialize in the tax area, ${ }^{17}$ and was recognized as an "income tax expert." 18 This expertise brought him into contact with a number of celebrities in the entertainment industry. $\mathrm{He}$ represented George Burns and Gracie Allen in their 1938 claim for a refund on their 1935 state income taxes. ${ }^{19}$ From 1937 to 1941 he prepared the income tax returns of W.C. Fields, and was called as a witness in the sensational 1949 trial over the comedian's estate. ${ }^{20}$ And in 1951 he represented actor Charles Coburn and four of his poker buddies charged with flouting the gambling ordinance of Beverly Hills. ${ }^{21}$ He kept an office in Los Angeles until 1984, when he died at the age of eighty-four. ${ }^{22}$ His estate plan created an endowment with the University of North Dakota Foundation, which the University has used to establish a law professorship in his name. ${ }^{23}$

Justice Sutherland's most distinguished alumnus was Francis Robison Kirkham, who clerked for the Justice during part of the 1930 Term and for the 1931, 1932, and 1933 Terms. ${ }^{24}$ Kirkham was born in Fillmore, Utah in 1904. His grandparents were among the earliest Mormon pioneers to settle in the Salt Lake Valley, and his mother and father met at Brigham Young University (BYU). His father went on to take a bachelor's degree at the University of Michigan, a law degree from the University of Utah, and a Ph.D. in education from the University of California at Berkeley. The senior Kirkham taught at BYU, served as Utah's director of education, and was the superintendent of the largest school district in the state. The Kirkham parents emphasized the importance of education: each of their six children graduated from college, and each of the three sons obtained an advanced degree. Francis' brother, Don, became a distinguished physicist. ${ }^{25}$

Kirkham was admitted to the Naval Academy at Annapolis for college, but at his father's insistence remained in Utah, studying for two years at the University of Utah and then at the Utah Agricultural College. As a young man he served in the National Guard, did a two-year mission for 


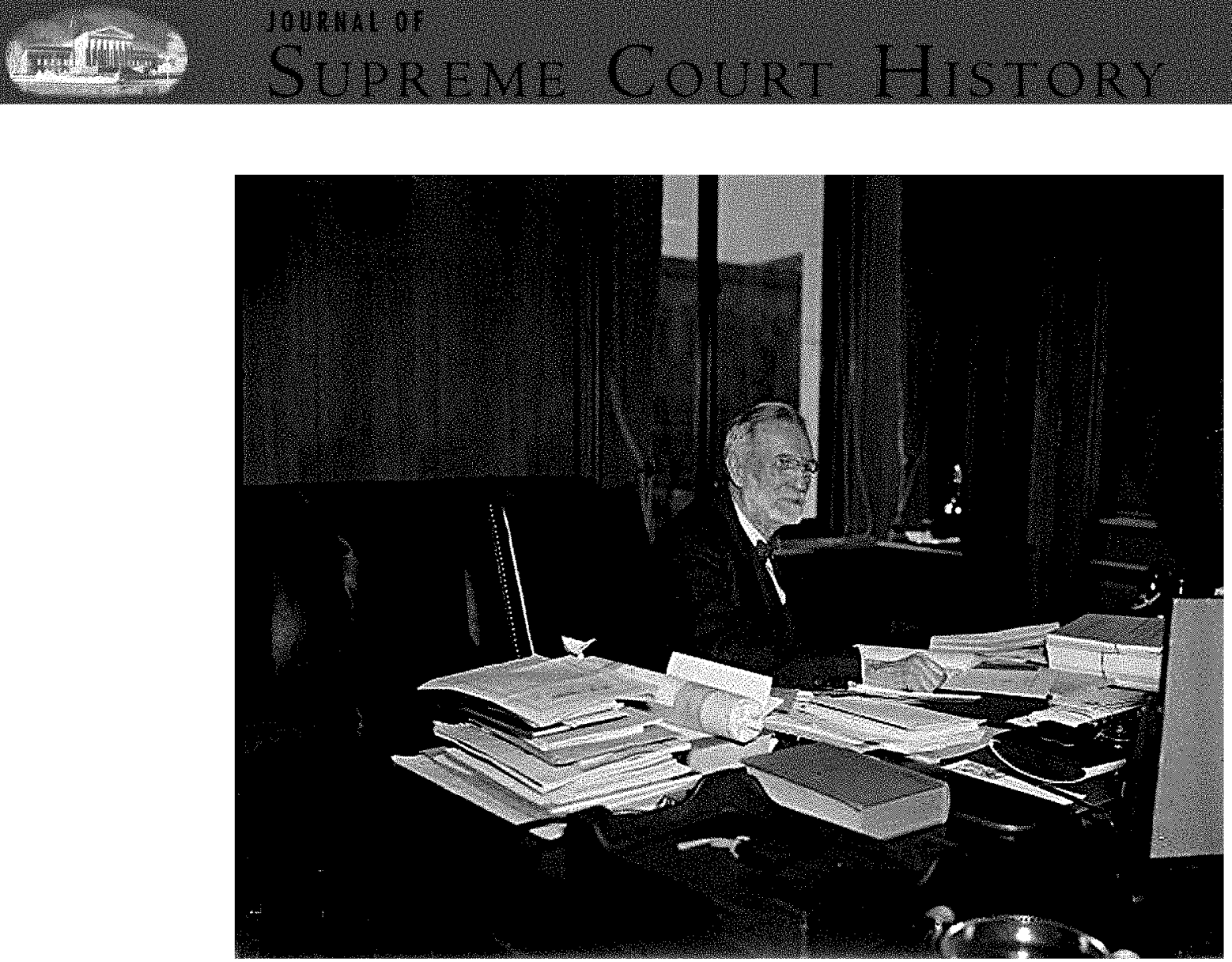

Justice George Sutherland served on the Supreme Court from 1922 to 1938 , but employed only four clerks during his tenure. He inherited his first clerk, S. Edward Widdifield, from his predecessor, Justice John $\mathrm{H}$. Clarke; three others were graduates of George Washington University's law school.

the LDS Church in England, and spent six adventure-filled months backpacking around Europe and the Middle East with a friend. For a time he worked at some of the farms his father owned, but regional droughts drove the father to New York to serve as the director of the National Child Welfare Association, and the son in 1927 to George Washington University (GWU) to complete his undergraduate degree and to study law. ${ }^{26}$

Kirkham received his A.B. from GWU in 1930, and graduated first in his law school class the following year. To pay his way through school, he worked part-time at the Interstate Commerce Commission and later in the Washington office of the Cravath firm. During Kirkham's final year of law school, a chance conversation between Justice Sutherland and Bill Allison, a Kirkham friend who was deputy clerk of the Supreme Court, resulted in Kirkham being invited to inter- view with the Justice. Sutherland winnowed the field to two candidates, Kirkham and a graduate of Columbia University Law School. Sutherland then arranged a competition for the finalists. He gave each of them several sets of the briefs and records of cases in the Supreme Court, and asked them to prepare memoranda for him. Kirkham labored all night in the law school library on the assignment, and Sutherland selected him for the position. Kirkham worked part-time for Sutherland alongside Alan Gray while he was completing his studies and taking the D.C. bar examination, on which Sutherland informed him that he received the highest score among the 480 students sitting for that administration. He began clerking for Sutherland full time at the outset of the 1931 Term. $^{27}$

As Sutherland's law clerk, Kirkham prepared statements analyzing petitions for certiorari and making recommendations 
concerning whether the writs should be granted. He also conducted research for the opinions that Sutherland wrote. Among his more notable contributions were the historical research appearing in Sutherland's 1932 majority opinion in Powell v. Alabama, ${ }^{28}$ the decision holding that the Due Process Clause entitled the "Scottsboro Boys" to competent defense counsel in a capital case, and the historical research appearing in Sutherland's dissent from Home Building \& Loan Association v. Blaisdell, ${ }^{29}$ the 1934 decision upholding the Minnesota Mortgage Moratorium.

Kirkham described the working atmosphere with Sutherland as "a very close personal relationship. . he was an extraordinarily wonderful person to be with and work with. A warm nature, very brilliant scholar, extremely appreciative ... you'd just do anything and he'd overpraise you for it and that'd make you work your tail off to do something better." Kirkham recalled an occasion on which Sutherland asked him to see whether he could find some authority in support of a particular statement contained in one of his draft opinions. Kirkham searched diligently, but came up empty. He went to Sutherland and said to him, "“Mr. Justice, I just can't find anything. Your statement is right, it should be the law, I just can't find the case that says that it is." Sutherland "looked up and smiled, picked up his pen, signed his opinion and said, "Well, it is now." ${ }^{\text {"30 }}$ At the conclusion of his clerkship with Sutherland in the summer of 1934, Kirkham stayed on to clerk with the "indefatigable" Chief Justice Hughes until December of $1935 .^{31}$

In 1929 Kirkham married Ellis Musser, whom he had known from his youth in Utah. Ellis, who had studied at the University of Utah and Mills College before marrying Francis, moved to Washington and completed her undergraduate studies at George Washington University in 1931. While Francis was working day and night clerking for Sutherland and Hughes, Ellis worked for the National Academy of Sciences, spent six months traveling in Europe and the Middle East, and completed her first year of medical school. Together the couple would have four children. ${ }^{32}$ Ellis was the older sister of Milton Musser, and Kirkham played a role in facilitating Milton's clerkship with Justice McReynolds during the Court's 1938 and 1939 Terms. $^{33}$

Ellis' medical studies were cut short when Francis concluded his clerkship with Hughes in December of 1935. Though Francis had accepted an offer to join the Cravath firm, the Kirkhams were apprehensive about living in New York. Judge Harold Stephens of the U.S. Circuit Court of Appeals for the D.C. Circuit, who was an old family friend, intervened and persuaded Kirkham to consider opportunities in other cities. On his own initiative, Stephens wrote letters of introduction for Kirkham to numerous firms around the country. Cravath gracefully released Kirkham from his acceptance, and, after interviewing in several cities, the Kirkhams decided to move to San Francisco in 1936 to join the firm of Pillsbury, Madison \& Sutro. As his partner James O'Brien relates, "His talents and skill were so quickly recognized that even senior partners soon vied for his help in major cases making their way to the Supreme Court." Kirkham became a partner at Pillsbury in 1940, and remained with the firm until 1960, when he left to serve as general counsel to Standard Oil. He returned to Pillsbury in 1970 , retiring as senior partner in $1991 .^{34}$

During his career Kirkham represented many of his clients before the Supreme Court of the United States. ${ }^{35}$ He became a Fellow of the American College of Trial Lawyers, a member of the American Law Institute, the chairman of the American Bar Association's section on antitrust law, and a member of two important national commissions on law reform: the Attorney General's National Committee to Study the Antitrust Laws (1953-55), and the National Commission on the Revision of the Federal Appellate 
System (1973). He was also the author of two highly regarded works, The Jurisdiction of the Supreme Court of the United States, and General Orders and Forms in Bankruptcy. ${ }^{36}$ He was a member of the American Judicature Society, the American Society of International Law, the Order of the Coif, and several clubs. He received the George Washington University Alumni Achievement Award in 1970 and the University of Utah Alumni Merit Honor Award in 1976. The Law School at Brigham Young University, on whose Board of Visitors he served, established a professorship in his name in 1989. He also served on the Board of Visitors of the University of Chicago Law School. He died in 1996 at the age of ninety-two. ${ }^{37}$

At Pillsbury, Kirkham always wore a dark blue suit, a white shirt, black shoes, and a black tie. ${ }^{38}$ His partners spoke of him with unreserved admiration. Turner H. McBaine described him as "an absolutely outstanding man: superb intellect, marvelous personality, ability to get along with people, and a man full of enthusiasm for what he was doing." "His legal writing was excellent," and his briefs were "a pleasure to read," "not only technically outstanding, but artistically outstanding, as a matter of the English language." Kirkham's "habits were not always regular, in the sense that no matter what time he started working in the morning, if he got into something, he might well be there at three the next morning. And he produced,time after time, legal miracles." 39 Wallace Kaapcke similarly portrays Kirkham as "a wonderful fellow," "the most welcoming and warm, friendly person," a "kind, accomplished gentleman." ${ }^{40}$ Kaapcke marveled at the way in which Kirkham "accomplished the brilliant results that he often did" in difficult cases, achieving "the impossible." explains James O'Brien, “Against all odds, he persuaded the antitrust division to permit the merger of Standard Oil Company of Kentucky and Standard Oil of California." "42 John Bates explains that Kirkham "was always looked upon as being the most powerful legal intellect in the firm. I mean he was the bright star; he was the real genius. He took on all the complicated antitrust cases." Kirkham "had a really powerful reputation in the legal community, and he deserved every bit of it. And yet he was and is a very humble, likeable, politic person."43 Yet Kirkham was not a retiring bookworm. Even as he got older, "[h]e'd still go any anyplace, anytime." ${ }^{, 44}$ As James O'Brien put it, "Kirkham is the kind of lawyer ... that was prepared to take off his coat and get down and wrestle on the barroom floor. ${ }^{, 45}$

O'Brien, who wrote the introduction to the interview that Kirkham provided for the Pillsbury, Madison \& Sutro Oral History Series, was particularly effusive in his praise. "Few men have come to the profession of law with greater gifts of mind, spirit, and will," O'Brien wrote. "None has used those exceptional gifts and experiences with greater skill in achieving a national reputation as a superb advocate" and "a devoted and compassionate friend." Kirkham had "a rare combination of qualities: a strong constitution, boundless energy and vitality, resourcefulness, the will and tenacity to master his profession," and "confidence in his capacity to deal with any issue that involved the law." "His pioneer background" had given him "a sturdy independence, a sense of responsibility," and "individual initiative." "Few lawyers" could "match the quality of his writing: clear and simple, plain and compelling, seemingly effortless." Kirkham was a "tall, handsome figure, dignified, courteous, with a warm, confident personality, a quick and easy smile, a resonant voice." He was "a formidable courtroom adversary" who had "made friends of his adversaries." O'Brien described Kirkham as a gentle, compassionate, modest person who loved "life," "nature," "song and laughter," "his myriad friends," and "his beautiful family." $\mathrm{He}$ 
was "a great lawyer" who "fashioned a memorable career at the Bar." It was, O'Brien concluded, "difficult to conceive that a single lawyer [could] have achieved so much in one lifetime." 46

John Wiley Cragun was Sutherland's final clerk, serving from the 1934 Term through the Justice's retirement during the 1937 Term. ${ }^{47}$ Cragun was born in Ogden, Utah in 1906. He arrived in Washington in 1924, and worked as a clerk, typist, and stenographer in the Department of the Interior for several years before receiving his A.B. from George Washington University in $1932 .{ }^{48}$ He then attended George Washington's law school while working simultaneously as a legal stenographer in the Washington office of Cravath, Swaine, \& Moore. He compiled "an excellent academic record," graduated in 1934 , and was promptly admitted to the D.C. bar. ${ }^{49}$ During his clerkship with Sutherland, Cragun occasionally took on special assignments for Chief Justice Hughes, and "established among the Justices and the employees of the Court a reputation for excellence, which

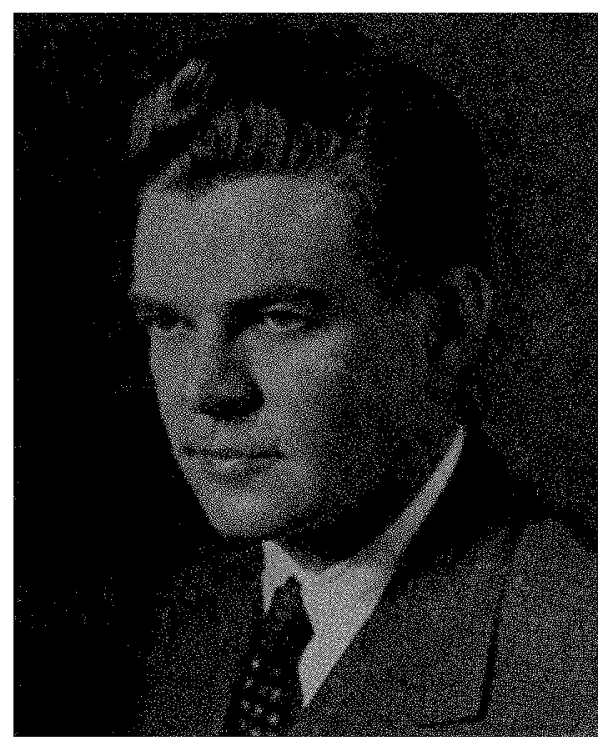

Sutherland hired two clerks originally from his home state of Utah, Francis R. Kirkham and John W. Cragun. Cragun (above) went into private practice and became an expert in administrative law. He also represented several Native American tribes. was later to play an important role in his professional practice." 50

For the rest of his life, Cragun engaged in an active Washington practice. Following his clerkship, Cragun entered a successful association and later partnership with what would become the firm of Wilkinson, Cragun \& Barker. ${ }^{51} \mathrm{He}$ went out on his own for five years beginning in 1945, and in 1950 and 1951 was associated with the specialized tax practice of D.C. lawyer Robert Ash. ${ }^{52}$ In 1951 he returned to the Wilkinson firm as a partner, and remained there until his death at the age of sixty-two in $1969 .{ }^{53}$ His clients included the National Grange and a large number of Native American tribes. ${ }^{54} \mathrm{He}$ was remembered as "an unusually expert brief writer" who "was often employed to prepare petitions for writs of certiorari to the Supreme Court of the United States." Indeed, a mid-century survey indicated that "he had achieved a higher degree of success in obtaining grants of certiorari than any other private practitioner." $" 55$

Cragun was a lawyer of national prominence. He served on a wide variety of professional committees, including as Chairman of the American Bar Association's Section on Administrative Law and Chairman of the ABA's Special Committee on the Code of Administrative Procedure. ${ }^{56}$ In the late $1940 \mathrm{~s}$, Cragun lectured on civil procedure at his alma mater. $\mathrm{He}$ was a member of numerous clubs, and was the founder and Recording Secretary of the Society for Appropriate Recognition of Elegant Mixed Metaphors. Cragun married three times. His first marriage, to Hazel Gabbard in 1931, produced three children before ending in divorce. $\mathrm{He}$ remarried to Hilda Henderson in 1957, but she left him widowed seven years later. His third and final marriage, to Priscilla A. Martin in 1965, endured until complications from emphysema brought about his untimely demise nearly four years later. ${ }^{57}$ 


\section{The Butler Clerks}

Although Congress had appropriated funds in 1919 so that the Justices could hire a law clerk and a stenographer, Justice Sutherland managed with just one clerk. Justice Butler, by contrast, employed two. One, John Francis Cotter, remained in Butler's employ for the Justice's entire tenure on the Court. Others joined Cotter for shorter stints of service. ${ }^{58}$

Cotter was born in 1900 in the District of Columbia, and graduated from its Central High School. As a young man he worked as a messenger in the Treasury Department, a stenographer for the Interstate Commerce Commission, and a clerk for the U.S. Shipping Board and the Census Bureau. He also served briefly in the Army during World War I. ${ }^{59} \mathrm{He}$ received his law degree from Catholic University in $1921,{ }^{60}$ and was admitted to the District of Columbia Bar in September of that year. ${ }^{61}$ After serving as a stenographer and law clerk to a local attorney for a little over a year, the young bachelor went to work for Butler in February of 1923, shortly after the Justice took his seat. ${ }^{62} \mathrm{He}$ was hired as a "stenographic clerk" at a salary of $\$ 2,000$, but was promoted to law clerk at a salary of $\$ 3,600$ for the 1925 Term. $^{63}$

At Butler's death, it was Cotter who carried out Butler's instructions that his Court papers be destroyed.$^{64}$ Cotter also served as the administrator of Butler's estate, and prepared his estate tax returns. ${ }^{65}$ Thereafter he embarked upon a successful career as an attorney in the Lands Division of the Justice Department, for which he is listed as counsel in a series of appeals before the federal courts between 1940 and $1956 .{ }^{66}$ In 1942 the nowconfirmed bachelor enlisted in the Army, and within fewer than four years he had risen to the rank of Major. He served as an officer in the J.A.G. Corps and as a member of the Claims Commission sitting in France, Belgium, and the United Kingdom. ${ }^{67}$ After his return from military leave he resumed his duties in the Lands Division, from which he retired in the latter part of $1955 .{ }^{68}$ From 1957 Martindale-Hubbell lists him as a lawyer in private, perhaps solo, practice, in Washington, D.C. ${ }^{69}$ though his absence from other public records during this period suggests that he may have been in semi-retirement. He died in November of $1978 .^{70}$

William A.D. Dyke, who clerked for Justice Mahlon Pitney for the portion of the 1922 Term preceding the Justice's stroke and retirement in December of that year, spent only the remainder of that Term in Butler's chambers. ${ }^{71}$ Before clerking for Pitney, Dyke worked as an assistant clerk in the U.S. Senate from 1918 to $1921^{72}$ and was initiated into the Order of the Elks. ${ }^{73}$ In 1921, he received an L.L.B. and a M.P.L. from Georgetown University, where he was the class poet. After leaving Butler, Dyke returned to Georgetown to earn an M.D. in 1929, and went on to pursue a medical career. ${ }^{74} \mathrm{He}$ is listed as a First Lieutenant serving in the Medical Corps of the U.S. Army Reserve at a Pennsylvania Civilian Conservation Corps camp in $1933 .^{75}$ Dr. Dyke died in an automobile accident in 1941 at the young age of forty-two, leaving a widow, Cuba A. Dyke. Seven years later, Mrs. Dyke met a dramatic end, collapsing and dying immediately following Christmas dinner. The couple, who are buried side by side at Arlington National Cemetery, apparently had no children. ${ }^{76}$

Norris Darrel1 joined Cotter in Butler's chambers as a law clerk for the 1923 and 1924 Terms. ${ }^{77}$ Darrell was born on St. Kitts in 1899, was brought by his parents to the United States the following year, and was naturalized in 1910. The son of a "modestly paid clergyman," as he would later describe his father, he served in the infantry during World War I. In 1923, he received his L.L.B. from the University of Minnesota, where he was elected to the Order of the Coif. The summer following his graduation from law school, Darrell was traveling on the West Coast and contemplating a career practicing 


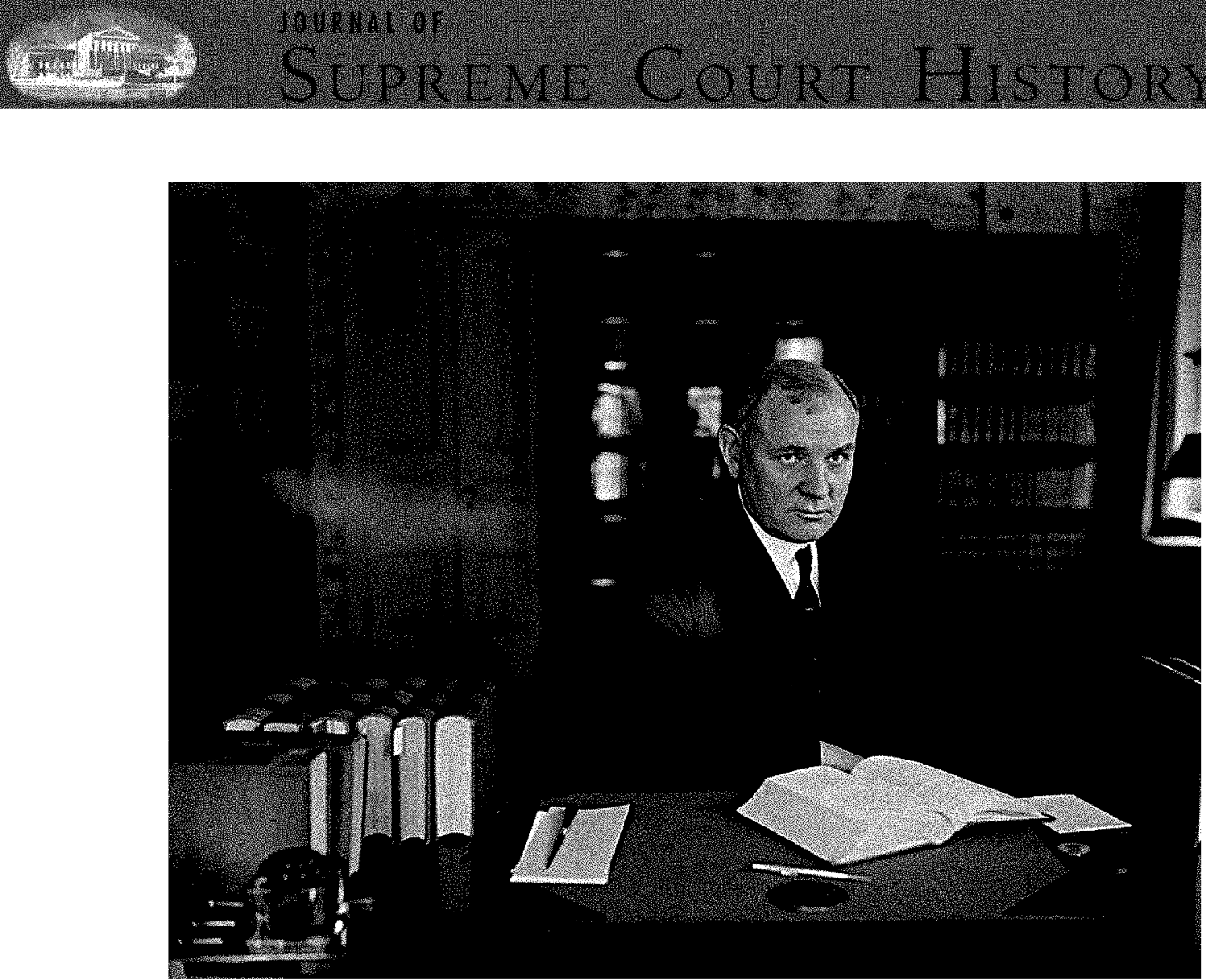

Pierce Butler (above) employed two clerks each Term during his service on the Court from 1923 to 1939. John Francis Cotter, a graduate of Catholic University Law School, remained in Butler's employ for the Justice's entire tenure, while six other clerks joined him for shorter stints of service. The Minnesota Justice hired several graduates from the University of Minnesota Law School; he himself had "read law" there after earning an undergraduate degree from Carleton College.

in that region when he received a telephone call from the dean of his alma mater. Dean Everett Fraser informed Darrell that Justice Butler had asked him to recommend a member of the graduating class to serve as a law clerk, and that Fraser had recommended Darrell. Fraser asked Darrell to cut his western trip short and to return to Minneapolis so that he might meet with Justice Butler to discuss the possibility. The conversation must have gone well, as Darrell soon found himself at Butler's elbow in Washington. ${ }^{78}$

The clerkship with Butler changed the course of Darrell's professional career. The Justice urged him to return to Minneapolis to practice, insisting that he would enjoy a fuller and happier life there. ${ }^{79}$ But Professor Noel Dowling, who had taught Darrell at Minnesota and recently moved to Columbia, encouraged the young lawyer to consider practicing in
New York. Dowling enlisted former Columbia dean Justice Harlan Fiske Stone in his campaign of persuasion, and it was at Stone's urging that Darrell interviewed with Sullivan \& Cromwell. Darrell was offered a position with Sullivan and two other Wall Street firms, and his future path was set during a consultation with Dean Fraser on a return trip to Minneapolis. Darrell held his breath as Fraser examined the letterhead of each of the firms listing their partners. Then, Darrell later reported, "he suddenly threw down one of them, pointed to the name of a partner far down the list who was unknown to me and said that I should by all means go there because he had taught that man when he was teaching Property: Future Interests at a law school in Washington, D.C., that the man never kept notes in class as expected-his notebook being usually blank except for doodles-but 


\section{Norris Darumir. - . . Minneapolis \\ Law}

Nipha Tau Onega, Mhi Delit Mh, Rebrint

Dosed Winnesolo Law Review, 3 , Garrick Club 1, 2, Presithen Gorie, Club s, A Wigit at an $1 \mathrm{~nm}$, , In the Zonc, , Hound Eist for

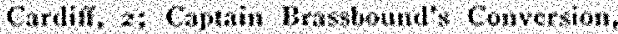
3) Wirguer , it Drily Reporter, 1, Scety Treas. Mialaw Chas, Tru G, blon Kapha: Strilont Dranstic Advisory Commites.

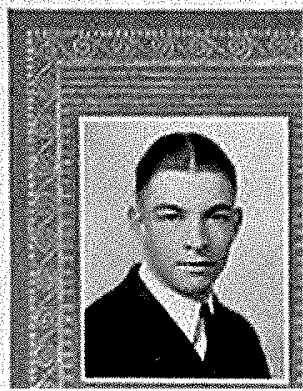

Norris Darrell, who clerked alongside Cotter during the 1923 and 1924 Terms, was recommended by Everett Fraser, dean of the University of Minnesota Law School. Darrell went on to develop a renowned practice in tax law at Sullivan \& Cromwell.

that he regularly had the highest marks in his class." The firm was Sullivan \& Cromwell; the doodling student was John Foster Dulles. Near the end of his career Darrell wrote that following Fraser's advice was a decision that he never regretted. ${ }^{80}$

In his conversation with Darrell about his future, Butler told him about two of his former associates from Minnesota who had pursued divergent professional paths. One accepted an offer with a New York firm and "worked hard in his practice, made a lot of money and gave a lot to charity but he never married. He rode the subways, was little known in his community and played no part in community affairs." The other lawyer declined a New York firm's offer and instead remained in St. Paul. He "lived very comfortably with his wife and family on his income of a hundred thousand to one hundred fifty thousand dollars a year, was widely known and greatly admired in his community in which nothing of great importance happened without his participation." Years later, Butler and Darrell "had a good laugh" over the story and the subsequent history of its protagonists. The man who went to New York was Carl Taylor. The man who stayed in St. Paul was William D. Mitchell, who went on to become Attorney General of the United States. After concluding his service in Washington, however, Mitchell did not return to St. Paul. Instead, he moved to New York and joined Taylor's firm. ${ }^{81}$
Darrell went on to enjoy a distinguished career with Sullivan \& Cromwell in New York, Paris, and Berlin. He was made a partner in 1934, eventually becoming both head of the tax group and vice-chairman of the firm, and remained with Sullivan \& Cromwell as counsel following his retirement from the partnership in 1976. He served on the boards of numerous corporations and professional organizations, including the American Law Institute (ALI), of which he was president for fifteen years and chairman of the council thereafter. He was also the chairman of the Supervisory Committee of the ALI Tax Project that culminated in the Internal Revenue Code of 1954. Darrell received several awards recognizing his professional achievements, including the University of Minnesota's Outstanding Achievement Award in 1965, the MarshallWythe Medallion from the College of William and Mary in 1967, and the New York Bar Association's Gold Medal Award for Distinguished Service in the Law in 1978. In 1953, the Eisenhower Administration approached Darrell about taking the position of undersecretary of the Treasury. Darrell didn't want the job and didn't want to leave New York, but also didn't feel that he could say no. Fortuitously, his senior partner, John Foster Dulles, who did not know of Darrell's preferences, inadvertently helped Darrell to wriggle off the hook. Dulles had been named Secretary of State, and his brother Allen, also 
a Sullivan \& Cromwell partner, had been tapped to head the CIA. As Dulles and Eisenhower were returning from a trip to Hawaii, Dulles talked the President out of the Darrell appointment, suggesting that it would be unfair to ask three senior partners from the same firm to serve the Administration at the same time. Dulles wrote to Leonard Hall, the head of the Eisenhower transition team, that were the Administration to appoint three Sullivan \& Cromwell partners to such important posts, "a rather frightening picture could be drawn by unfriendly persons." A relieved Darrell thus was able to remain in his beloved New York. ${ }^{82}$

Darrell married Doris Clare Williams in 1925, and together they had two sons. Doris passed away in 1943, and in 1945 Darrell married Mary Hand Churchill, the divorced daughter of Judge Learned Hand, the liberal icon who had derided Butler as one of the "mastiffs" back in the $1920 \mathrm{~s}$ and $1930 \mathrm{~s} .{ }^{83}$ It was Darrell who, as literary executor of Hand's estate, persuaded Gerald Gunther to write Hand's biography. ${ }^{84}$ In 1966 Darrell joined Warren Christopher, Lloyd Cutler, Erwin Griswold, Burke Marshall, Louis Pollak, Eugene Rostow, and ten other leading lawyers in a letter to Congress supporting the constitutionality of the proposed Civil Rights Act of $1966 .^{85}$ Darrell died in Manhattan in 1989 at the age of ninety, survived by Mary, the two sons from his first marriage, a stepson, and two grandchildren. ${ }^{86}$

After Darrell left Butler's employ, Cotter was promoted to law clerk and served alone during the 1925 and 1926 Terms. Butler hired Richard L. Sullivan to work alongside Cotter during the 1927 Term at the "stenographic clerk" salary. ${ }^{87}$ Sullivan was born in 1901, and by 1926 had graduated from both college and law school at the University of Minnesota. ${ }^{88}$ By the early $1930 \mathrm{~s}$, Sullivan had been admitted to the Supreme Court bar and become associated with the Manhattan firm of Kirlin, Campbell, Hickox, Keating, \& McGrann. ${ }^{89}$ $\mathrm{He}$ was a member of the Maritime Law

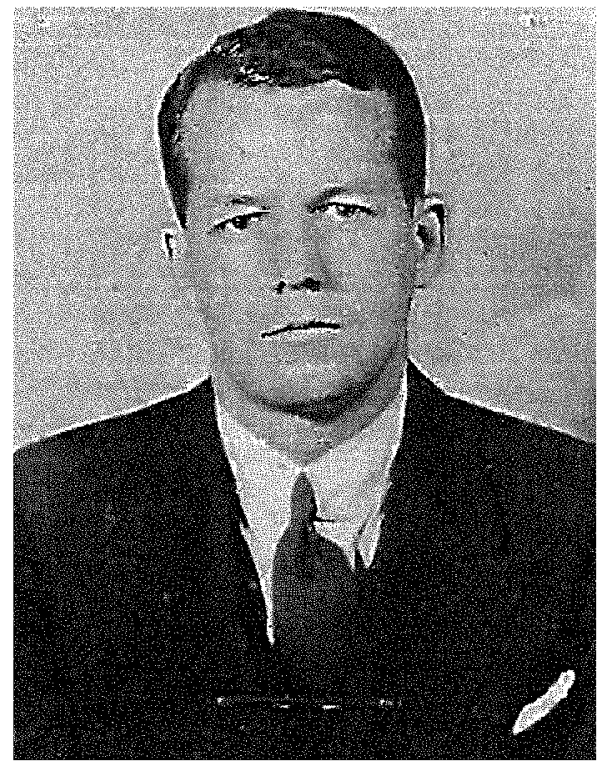

William Devereaux Donnelly, also a graduate of the University of Minnesota Law School, served as a Butler clerk from the 1928 Term through the 1936 Term. He went on to private practice and argued several cases before the Court, most notably the landmark Free Exercise case, Sherbert v. Verner (1963). Like Adell Sherbert, the plaintiff he represented, Donnelly was a Seventh-day Adventist, and he represented his church in other legal proceedings as well.

Association of the United States, and his practice focused on admiralty matters. ${ }^{90}$ In 1933 he became a member of the Aeronautics Committee of the Bar of the City of New York, on which he served until at least $1937 .{ }^{91} \mathrm{He}$ practiced with the Kirlin firm until $1953 .{ }^{92} \mathrm{He}$ died in 1970 in Oakland, California. ${ }^{93}$

William Devereaux Donnelly served as Cotter's co-clerk from the 1928 Term through the 1936 Term. $^{94} \mathrm{He}$ earned the lower "stenographer" salary, but performed all the duties of a law clerk. Donnelly was born in Cass Lake, Minnesota in 1905, and graduated from Central High School in Minneapolis. He came to Washington in 1928 after taking his law degree from the University of Minnesota, where he also received his bachelor's degree. He married Patricia Arnold in 1932. After clerking for Butler, he worked as an attorney 


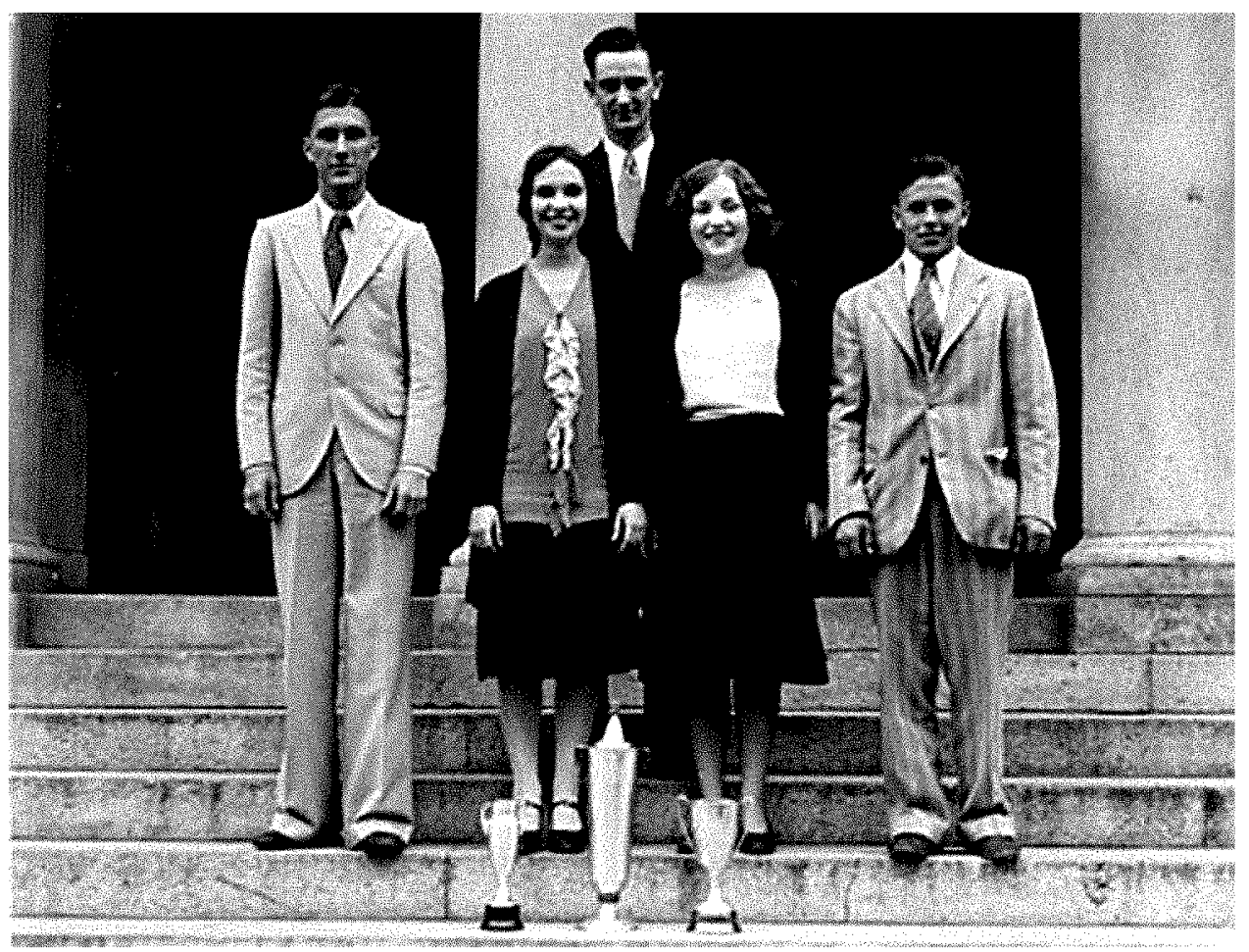

Luther E. "L.E." Jones, Jr. co-clerked with Cotter during the 1938 Term and until the Justice's death in November of 1939. Before clerking for Butler, Jones (left) served on the staff of freshman Congressman Lyndon B. Johnson, who had been his speech coach on the Sam Houston High School debate team (pictured, with Johnson at top, in 1931).

in the Lands Division of the Justice Department from 1937 to 1940 , serving as special assistant to the Attorney General in 1939 and $1940 .^{95}$ In 1940 he went to work for the newly formed Washington firm of Cummings \& Stanley (later Cummings, Stanley, Truitt \& Cross). ${ }^{96}$ The Cummings in question was, of course, Homer Cummings, Franklin D. Roosevelt's former Attorney General and the author of the infamous Court-packing plan introduced during Donnelly's final year of service with Butler. ${ }^{97}$ Donnelly engaged in a widely varied practice with the Cummings firm, ranging from civil and criminal litigation to estate planning. ${ }^{98}$ Shortly after joining the firm, for instance, Donnelly assisted Cummings in representing the notorious Chicago gambler, William R. Johnson, on charges of tax evasion. In 1946, Donnelly was called before a special federal grand jury looking into how Johnson had managed to stay out of prison for five-and-a-half years following his conviction. ${ }^{99}$

Donnelly was admitted to the Supreme Court bar in $1939,{ }^{100}$ and periodically briefed and argued cases before the Court. ${ }^{101}$ The capstone of his career as a Supreme Court advocate came with his successful representation of the petitioner in the landmark Free Exercise case of Sherbert v. Verner. ${ }^{102}$ Like Adell Sherbert, Donnelly was a Seventh-Day Adventist, and he represented the Bethesda community in the Church's General Conference. ${ }^{103}$ Donnelly represented his church in other legal proceedings as well, ${ }^{104}$ and in 1955 testified on its behalf at hearings on proposed amendments to the Fair Labor Standards Act held before the Senate Committee on Labor and Public Welfare. ${ }^{105}$ In 1964 he joined 227 other constitutional scholars and lawyers in signing a letter to the House Judiciary Committee co-authored by Brandeis clerk 
Paul Freund in opposition to the proposed Becker Amendment to the Constitution, which would have overruled the recent school-prayer and devotional-Bible-reading decisions of Engel v. Vitale and Abington School District v. Schempp. ${ }^{106}$

Donnelly was a partner in the Cummings firm by $1945,{ }^{107}$ and remained with the firm until $1956,{ }^{108}$ when he established his own solo practice. ${ }^{109} \mathrm{~A}$ decade later he formed a partnership with a young lawyer named Gerald Golin, ${ }^{10}$ and he continued to practice with Donnelly \& Golin until his death in $1975 .^{111} \mathrm{He}$ was an active member of the District of Columbia Bar Association, ${ }^{112}$ where he served on committees with John Cragun. ${ }^{13} \mathrm{He}$ also belonged to the University Club and the Congressional Country Club. A widower, he died of a stroke at the age of sixty-nine, leaving four children. ${ }^{114}$

Irving Clark joined Butler for the 1937 term, ${ }^{115}$ immediately following his graduation from Harvard Law School. A native of Duluth, Clark received his bachelor's degree in literature and philosophy from the University of Minnesota in 1934. In 1938, the Justice's son Francis met Clark while visiting the elder Butler in Washington, and he asked Clark to join his St. Paul firm upon the completion of his clerkship. Excepting his service in the Army during the Second World War, Clark remained with Doherty, Rumble \& Butler from 1938 until his retirement in 1985, acting as the firm's managing partner from 1953 to $1975 .{ }^{116} \mathrm{His}$ practice was varied, ${ }^{117}$ but it centered on agricultural cooperatives and nonprofit organizations. ${ }^{118}$ He served on the boards of many charitable foundations, ${ }^{119}$ and he was the board chairman of the Twin Cities' antipoverty agency in the $1960 \mathrm{~s} .{ }^{120} \mathrm{He}$ died at the age of eighty-four in January of 1997 , leaving a widow, three children, and three grandchildren. $^{121}$

Luther E. "L.E." Jones, Jr. was the last clerk to team up with Cotter, working for Butler during the 1938 Term and until the
Justice's death in November of 1939. ${ }^{122}$ Jones was in some ways Butler's most interesting case, in part because he was a protégé of Lyndon Baines Johnson. Jones was the son of an impoverished druggist, and grew up in a Houston slum from which he was desperate to escape. ${ }^{123}$ As a student at Sam Houston High School working part-time as a delivery boy, Jones was remembered as "tall, handsome, brilliant, but stiff and aloof - 'smart as hell, but cold as hell." "124 In Jones's senior year of 1930-1931, Johnson came to teach at Sam Houston, and under the tutelage of his new public speaking instructor and debate coach Jones progressed to the finals of the Texas State Debate Championship. His loss by a narrow vote of three-two actually prompted his deeply disappointed and notoriously uncouth coach to vomit on the spot. ${ }^{125}$ After his graduation in 1931, Jones worked his way through two years at Rice University (then Rice Institute), but he feared that he would be unable to secure employment upon graduation. Johnson had in the meantime left teaching to become secretary to Congressman Richard M. Kleberg, and asked Jones to come to Washington to serve on Kleberg's staff at a salary of $\$ 1,100$ a year. Johnson wrote to him, “'I know you are going places and I'm going to help you get there,"' urging him that the place to begin was in a government position in Washington. ${ }^{126}$ Jones insisted that he needed a salary of $\$ 1,200$, and Johnson cut his own salary in order to provide the extra $\$ 100 .^{127}$ Jones worked out of the Corpus Christi office from August to December of 1933, when he went to Washington. ${ }^{128}$ There he shared a small basement room in the Dodge Hotel with Johnson and Gene Latimer, Jones's high school debate partner who had come to Washington to work for Johnson the preceding summer. Each of the three roommates paid rent of fifteen dollars per month, and shared a bathroom with the adjoining room. ${ }^{129}$

Jones's clerkship with Butler must have seemed like a stroll in the park after working for Lyndon Johnson. Johnson "drove himself 
and his staff relentlessly."130 "They worked phenomenally hard-fourteen-, sixteen-, often eighteen-hour days," frequently seven days a week. ${ }^{131}$ Jones reported for work at 7:30 AM and often could be found at his desk at midnight. ${ }^{132}$ Johnson forbade them to take a break to drink a cup of coffee, smoke a cigarette, or receive a personal telephone call. 133 "Even going to the bathroom was frowned upon."134 Johnson "insisted on perfection," Jones recalled, and, when he first started made him rewrite and retype hundreds of letters, no matter how long it took. ${ }^{135}$ Johnson would compare members of his staff unfavorably in order to instill competition among them. ${ }^{136}$ LBJ reserved his greatest abuse for the scholarly Jones, who was the best educated and most independent and selfcontained member of his staff. 137 "He would publicly ridicule any error he found in one of his letters, belittling his style of writing, his spelling, his typing, or any failing that put him in a subordinate position." 138 The "stiff" and "prim" Jones was also the first victim of what became Johnson's lifelong, revolting practice of insisting that subordinates come into the bathroom with him to receive instructions or take dictation while he sat on the toilet defecating. ${ }^{139}$ Jones "would stand with his head and nose averted, and take dictation," Latimer later told Robert Caro. ${ }^{140}$ For Jones "it was a source of humiliation and a means by which Johnson dominated him or exercised control." ${ }^{141}$ Jones was understating the matter when he later reflected that "Lyndon Johnson was a hard man to work for."142

"At times, Latimer and Jones found it nearly impossible to keep working" for Johnson. "He was so demanding and occasionally so overbearing and abusive that they periodically wanted to quit."143 But other considerations led Jones to persevere. First, this child of the Houston slums was very ambitious, and LBJ cultivated that ambition, telling him, "You work hard for me, and I'll help you." Later in life Jones would recall, "I always had the feeling that if I worked for
Lyndon Johnson, goodies would come to me . . . I was on the make, too . . . I wanted to improve myself." 144 Second, Jones was personally drawn to Johnson's own talent, energy, and ambition. Years later, Jones would report that "[m]ost people who had anything to do with Lyndon Johnson loved him ... the people who worked for him liked him. He had some faults, but most people were willing to overlook them because the guy was obviously a genius in politics."145 "I always felt like we were making history," Jones added. ${ }^{146}$ "[T] he atmosphere was full of challenge, and this guy's enthusiasm was just absolutely contagious." Even then, Jones and his co-workers thought it was likely that Johnson would one day be President. They were convinced that he was "going to be a man of destiny."147 Johnson, whom Jones later remembered as "a steam engine in pants," 148 drove himself as hard as he drove his staff, and his fierce loyalty to his subordinates inspired reciprocal loyalty from them. "Both Jones and Latimer recall that when all was said and done, they liked, even loved Lyndon Johnson." 149

One illustration of Johnson's concern for his staff occurred when Jones and Latimer decided to enroll in evening classes at Georgetown's Law School in the fall of 1934. Johnson gave each of them a raisefor Jones it was an additional $\$ 150$ per yearand made sure that they had two to three hours free each day to study. ${ }^{150}$ (Jones turned out to be a diligent student, completing his first year of law school at Georgetown; but Johnson, who briefly enrolled along with them, never studied, didn't enjoy the experience, and soon dropped out with what he called a "B.A.Barely Attended." ${ }^{151}$ During the fall of 1934, Johnson and Jones also worked together on liberal firebrand Maury Maverick's successful congressional campaign. ${ }^{152}$ But soon Jones had saved enough money to pay tuition at the University of Texas Law School, and in the late spring of 1935 he returned to Austin to complete his legal studies. He told Maverick's 
son that he "had to get away" from Johnson, or he'd "be devoured."153

As it would happen, Johnson also returned to Texas in the summer of 1935 , to head the Texas chapter of the National Youth Administration (NYA). That summer, Jones worked as a part-time administrative assistant for Johnson at the NYA in Austin, and he continued to do so briefly after beginning his studies in the fall. For a time he lived with Lyndon and Lady Bird in an upstairs room of their Austin duplex, and during this period he looked on Lyndon as an older brother with whom he was proud and excited to be associated. ${ }^{154}$ In his third year of law school, Jones worked as an apprentice for the firm of Johnson's patron and mentor, Texas State Senator Alvin J. Wirtz, and he was present in Wirtz's office for the conference between Johnson and Wirtz during which Johnson decided to run for Congress. ${ }^{155}$ Jones worked as an advance man for Johnson's successful 1937 congressional campaign, driving a sound truck announcing Johnson's imminent appearance through small towns in Texas. ${ }^{156}$ Jones graduated from the University of Texas Law School in June of 1937, and then moved to Washington to work as a temporary secretary in the offices of Kleberg and Johnson until the new congressman helped him to secure a job as a briefing attorney in the Lands Division of the Justice Department that December. ${ }^{157}$ During his stint at the Justice Department, Jones continued to lend a hand in Johnson's office in the evenings and on the weekends. $^{158}$

Jones went to work for Butler in October of 1938, and remained with the Justice until Butler's death in November of 1939. Like Donnelly, he earned the lower "stenographic clerk" wage, but he worked alongside Cotter preparing critical analyses of certiorari petitions and researching opinions for the Justice. Jones then worked on a temporary basis in LBJ's congressional office while he looked for another full-time position. ${ }^{159}$ There he encountered the young
John Connally, who had joined Johnson's staff earlier in the year. Randall Wood reports that, "[a]mong his fellow roomers at the Dodge, Connally quickly gained a reputation for vanity. Luther Jones remembered him standing in front of the mirror by the hour brushing his lustrous, wavy hair." ${ }^{160}$ Jones soon found steadier work back at the Lands Division, but in January of 1940 Wirtz became Undersecretary of the Interior, and he hired Jones to serve as his executive assistant. After a year of service at Interior, Jones returned to the Lands Division offices in Houston and Corpus Christi to work on federal condemnation cases for land for the Naval Air Station. He took an indefinite leave from the Justice Department in December of 1942 to enlist in the Army. ${ }^{161}$

During his time with Wirtz, Jones still periodically performed services for Johnson. One Sunday morning at Johnson's Dodge Hotel apartment, Jones had the honor of introducing Johnson to Jake Pickle. ${ }^{162}$ Jones and Pickle had been Delta Theta Phi fraternity brothers at the University of Texas, and Pickle was then a young member of the Texas National Youth Administration who had been summoned to Washington to discuss a proposed highway project with Johnson. Little did they know at the time that Pickle would later become Johnson's successor to the congressional seat, which Pickle would hold for thirty-one years. ${ }^{163}$ As Pickle relates the story, "As I prepared myself for the big meeting, Luther kept telling me how important LBJ was, how the Congressman was going places, and how, if I played my cards right, I could go places, too. We all could. 'You should watch him, Pickle!,' Luther said. 'He's amazing. He'll have you doing things you never thought possible. Big things! Important things!",164

They entered the apartment to find Johnson seated "on the throne," as Pickle put it. Pickle ducked back behind a door, but Johnson insisted that Luther join him in the 
bathroom. After a few minutes, Pickle relates, Johnson said, "'Luther, hand me some more paper!' And Luther did." 165 After Johnson had concluded his "business" in the salle de bain, the three men had a meeting about a proposed highway project. Pickle reports that "[n]othing was settled, but the meeting gave Johnson the chance to observe me, and vice versa. Of course, I had already observed more of Johnson that day than I had anticipated! . . . if I had looked forward to a personal meeting, I sure got one!"166 "That day, as we left Johnson's room," Pickle concludes the story, "I couldn't resist sticking it to Luther. 'You're right,' I said. 'Johnson does have you doing things you never thought possible. Important things! For instance, I notice you did a fine job handing him that paper!"” "Luther," Pickles adds, "took it good-naturedly." 167

Jones was destined to go on to even bigger and more important things. After serving as a second lieutenant in the Army during the War, he returned to Corpus Christi, this time as a full-time assistant to City Attorney Oliver Cox. ${ }^{168}$ In 1947 he entered a successful solo practice specializing in criminal law and oil and gas law. ${ }^{169}$ The following year Johnson called on him in a moment of crisis, asking Jones to join the legal team representing Johnson in the controversy arising out of the disputed Texas Democratic Party United States Senatorial Primary Election of 1948. Jones answered the call of duty, and Johnson went on to win a seat in the Senate, but this marked the end of their professional association. ${ }^{170}$ In 1958 Jones was elected to serve as a member of the Board of Directors of the National Association of Criminal Defense Lawyers. ${ }^{171}$ In 1965 , President Johnson had his old debate student and other honored guests bussed from Corpus Christi to the little one-room schoolhouse just down the road from the LBJ Ranch to witness the signing of the historic Elementary and Secondary Education Act. ${ }^{172}$ That same year, Jones was honored by the Texas State Bar for his distinguished service. A magazine profile published in 1968 characterized Jones as a "lawyer's lawyer," the "finest appellate lawyer" in Texas, and "the man with probably the finest technical legal knowledge in the state." "As a money earner," the article proclaimed, "he is probably in the top fivepercent of Texas lawyers; as a legal scholar he is second to none. Many colleagues consider him the finest appellate lawyer in the country." 173 That year Jones was among 250 honored guests at a White House reunion of longtime friends of Lyndon and Lady Bird. ${ }^{174}$ In 1968 he also sat on the State Bar's committee charged with revising the Texas Code of Criminal Procedure, and was made first assistant district attorney for Nueces County. ${ }^{175} \mathrm{He}$ retired from that position in 1970 in order to spend time with his family and to pursue his interests in philosophy, literature, travel, and dancing, ${ }^{176}$ but he continued to publish law review articles and to engage in occasional private practice into the 1980s. ${ }^{177}$ Throughout his professional career, Jones retained his fierce independence. He "would never join a law firm, because he did not want partners." Even "at the peak of his career, when he was earning impressive legal fees, he worked alone in a converted, book-lined garage behind his house in Corpus Christi." 178 Luther Jones died at the age of eighty-five in September of 1999, survived by his wife, four children, and nine grandchildren. ${ }^{179}$

\section{Conclusion}

The careers of some of the clerks for these "conservative" Justices may seem at first blush counterintuitive, but only because of the power of such reductive political taxonomy to mislead. It may seem odd that Luther Jones became one of the nation's leading criminal defense attorneys, until we recall that Chief Justice Hughes regarded Butler as a stickler for the protection of the rights of the accused, ${ }^{180}$ so much so that his 
colleague Justice Stone thought that Butler was soft on crime. ${ }^{181}$ It may seem strange that John Cragun became one of his generation's leading lawyers for Native American tribes, until we are reminded that Justice Van Devanter was an Indian law expert whose colleagues regarded him as "the Indians' best pal" on the Court. ${ }^{182}$ The philanthropic activities of clerks such as George Howland Chase, Norman Frost, Tench Marye, and Irving Clark may seem puzzling until we reflect that Justice McReynolds was a generous philanthropist during his life and left the bulk of his estate to charity. ${ }^{183}$ Upon closer inspection, these ostensible ironies dissipate.

Some of the personal and professional relationships of these clerks might also seem at first glance surprising: Chester Gray's secretarial position with Assistant Navy Secretary Franklin D. Roosevelt; Allan Sherier's father's secretarial job with labor leader Samuel Gompers; Luther Jones's secretarial post with the young Lyndon Johnson; Norris Darrell's marriage to Learned Hand's daughter;William Donnelly's partnership with Homer Cummings. The last of these, which notably did not occur until after Justice Butler's death, may remain puzzling even upon reflection. But at least some of these pairings seem less startling when we recall that Butler's first law partner was Stan Donnelly, the son of Butler's friend, the Populist leader Ignatius Donnelly; ${ }^{184}$ that McReynolds was a crusading trustbuster appointed by Theodore Roosevelt and Woodrow Wilson; ${ }^{185}$ and that regular Republicans Van Devanter and Sutherland reportedly got along very well with their more liberal colleagues. ${ }^{186}$ With the exception of McReynolds, these Justices could disagree without being disagreeable.

It is also noteworthy that so many of the Four Horsemen's clerks pursued careers in public service, and particularly with the federal government. There are at least two possible factors helping to explain this. First, particularly in the 1930s, the expansion of the federal government often offered more promising career prospects to young lawyers than did the private sector. ${ }^{187}$ Relatedly, many of these clerks were raised and/or educated in Washington, and probably wished to remain there. Washington was a government town, and the government was where the employment opportunities lay. At first blush it may seem curious that so many of these clerks entered government service when their Justices had fought so tenaciously for limited government. And to be sure, there is no gainsaying the irony of the subsequent activities of some of the McReynolds clerks: John Fowler's work on the Gold Clause Cases; Tench Marye's and T. Ellis Allison's service in the National Recovery Administration; Allison's contributions to the drafting of the Social Security Act; Marye's work for the Social Security Administration. Indeed, one is tempted to wonder whether these activities may have been in part reactions against their experiences with the Justice. At the same time, however, we must remember that limited government is not no government, and that with the exception of Butler, who served on the Court for sixteen years, each of the Four Horsemen spent the bulk of his professional life in some form of public service. ${ }^{188}$ Thus, it is misleading to characterize Sutherland or his fellow Horsemen as men "against the state." 189 They were instead, like many of their clerks, men of the state.

A review of the careers of the clerks of the Four Horsemen also serves to highlight the anomalous character of the case of John Knox, the only clerk of the Four Horsemen about whom much has been written previously. To be sure, only a few of these men rose to what might be regarded as the heights of their professions. But a great many of them had interesting and varied careers, achieving admirable success in business, private practice, government service, or some combination of these. Moreover, unlike the unfortunate, isolated Mr. Knox, most of them seem to have been blessed with fulfilling family and social lives, and were actively engaged in the affairs of their communities. 
This may help to explain why these other clerks did not write comparable remembrances of their service in chambers. Unlike Mr. Knox, who was lonely and often at loose ends, they had busy lives and other things to do.

Despite all of the interesting variation in the careers of the clerks of the Four Horsemen, however, they share one common similarity: Unlike the clerks for Holmes, Brandeis, and Stone, and their many successor Justices, not a single one of them developed a career as a law professor. This, too, may help to account for the absence of a clerkship remembrance literature, which has been generated predominantly by academics. And relatedly, I would suggest that this fact has had a powerful effect on the ways in which these Justices have been perceived by the academy, and by the legal profession at large. But that is a story for another day. ${ }^{190}$

Author's Note: Thanks to Patty Cushman, Clare Cushman, Joel Goldstein, Dennis Hutchison, and the participants in a faculty workshop at St. Louis University School of Law for helpful comments, and to Patrick Bottini, Carli Conklin, Anna Crandall, Trez Drake, Jessica Ettinger, Samantha Glass, Dwight King, Beth Klein, Lisa Meissner, and Chris O'Byrne for indispensable research assistance. I am grateful to the Bancroft Library of the University of California at Berkeley for permission to quote from the Pillsbury, Madison \& Sutro Oral History Series.

\section{Endnotes}

\footnotetext{
${ }^{1}$ Employment Record of Edward S. Widdifield, National Personnel Records Center, National Archives at St. Louis (on file with the author) (hereinafter "Widdifield Employment Record"). George Sutherland's clerks' dates of service were provided by the Supreme Court of the United States Library in correspondence dated June 26, 2002 (hereinafter Supreme Court Library Correspondence). While there is no complete list of all Supreme Court law clerks, the Library maintains unofficial internal files relating to clerks' service at the
}

Court, which it recognizes may contain incomplete and unverified information.

${ }^{2}$ Widdifield Employment Record; 2 Polk's Traverse City And Grand Traverse County Directory: 1901-1902, 106 (1902).

${ }^{3}$ Widdifield Employment Record; ARTEMUS WARD \& DAVID L. WEIDEN, SORCERER'S APPRENTICES: 100 YEARS OF LAW CLERKS AT THE UNITED STATES SUPREME COURT 32 (2006); Former Aide of Supreme Court Dies, WASH. POST, Oct. 2, 1960, p. B6; Widdifield, 74, Retires As Supreme Court Aide, WASH. POST, Feb. 1, 1949, p. 13.

${ }^{4}$ Widdifield Employment Record; OFFICIAL CONGRESSIONAL DIRECTORY 218 (2d ed. 1914); OFFICIAL CONGRESSIONAL DIRECTORY 190 (1st ed. 1915); S. Doc. No. 627, at 18 (1914) (Report of the Secretary); S. Doc. No. 1, at 11 (1915) (Report of the Secretary); S. DOC. NO. 556, at 11, 21 (1916) (Report of the Secretary); 1916-1 CONG. DIR. 215; Letter from Christopher J. Doby, Financial Clerk, United States Senate, to the author, March 20, 2014 (on file with the author); Former Aide of Supreme Court Dies; Widdifield, 74, Retires as Supreme Court Aide.

${ }^{5}$ Widdifield Employment Record; WARD \& WEIDEN, SORCERER'S APPRENTICES at 32; Former Aide of Supreme Court Dies; Widdifield, 74, Retires as Supreme Court Aide.

${ }^{6}$ Widdifield Employment Record; Former Aide of Supreme Court Dies; Widdifield, 74, Retires as Supreme Court Aide; OFFICIAL CONGRESSIONAL DIRECTORY 257 (2d ed. 1931); Miss Widdifield Will be Bride of E.H. Fraser, WASH. POST, June 2, 1935, at S2; Email from Katherine Logan, CPP, Director of the Office of Payroll and Benefits, U.S. House of Representatives, to the author, April 29, 2014 (on file with the author).

${ }^{7}$ Widdifield to Black, Aug. 12, 1937, Box 442, Hugo L. Black MSS, LC, quoted in TODD C. PEPPERS, COURTIERS OF THE MARBLE PALACE: THE RISE AND INFLUENCE OF THE SUPREME COURT LAW CLERK 61 (2006).

${ }^{8}$ Former Aide of Supreme Court Dies; Obituary 8 - No Title, WASH. POST, Oct. 2, 1960, p. B6.

${ }^{9}$ Francis R. Kirkham, "Sixty Rewarding Years in the Practice of Law: 1930-1990," an oral history conducted 1985-1990 by Sarah Sharp and Carole Hicke, Regional Oral History Office, The Bancroft Library, University of California at Berkeley 11-12 (1994) (hereinafter "Kirkham Oral History"). See also Supreme Court Library Correspondence.

${ }^{10}$ James E. Gray, 21 N.D. B. BR. 125 (1944).

${ }^{11} 1$ THE MARTINDALE-HUBBELL LAW DIRECTORY 1308, XI, $73^{\text {rd }}$ Annual Edition (MartindaleHubbell, Inc. 1941), microformed on LLMC MartindaleHubbell, Directories (1941) No. 92-001A F5; Area Briefs:UND's Zierdt Gets Law Professorship, GRAND 
FORKS (N.D.) HERALD, Nov. 28, 2001, 2001 WLNR 2295318.

12 http://www.walshhistory.org/publications/walsh-heritage/Walsh-Heritage-Volume-1/files/assets/basic-html/ pagel64.html, p. 169.

${ }^{13}$ See, e.g., $\$ 461,650$ in Sales, Recently Effected, Reported by Firm, WASH. POST, Nov. 6, 1927, at R5 (Gray purchase of home in Chevy Chase, Maryland); Legal Notices, WASH. POST, Oct. 7, 1933, at 21 (Gray publication of legal notice stating his occupation and office address in the Old Shoreham Building); http:// www.walshhistory.org/publications/walsh-heritage/ Walsh-Heritage-Volume-1/files/assets/basic-html/ pagel64.html, p. 169.

${ }^{14}$ See, e.g., Jewel Tea Co., Inc. v. United States, 90 F.2d 451 (2d Cir. 1937); Keener Oil \& Gas Co. v. Commissioner, 32 B.T.A. 186 (1935); Anderson v. P. W. Madsen Inv. Co., 72 F.2d 768 (10th Cir. 1934); Severs Hotel Co. v. Commissioner of Internal Revenue, 62 F.2d 1080 (10th Cir. 1932).

${ }^{15} \mathrm{http}: / / \mathrm{www} . w a l s h$ history.org/publications/walshheritage/Walsh-Heritage-Volume-1/files/assets/basichtml/pagel64.html, p. 169; Charles Curtis, Jack Gage Wrecks Par, L.A. TIMES, June 3, 1939, at 10 (listing Gray as a resident of the San Diego suburb of Lakeside).

${ }^{16}$ See, e.g., 1 THE MARTINDALE-HUBBELL LAW DIRECTORY $1348,70^{\text {th }}$ Annual Edition (MartindaleHubbell, Inc. 1938), microformed on LLMC MartindaleHubbell, Directories (1938) No. 92-001A F5; 1 THE MARTINDALE-HUBBELL LAW DIRECTORY 119 , $87^{\text {th }}$ Annual Edition (Martindale-Hubbell, Inc. 1955), microformed on LLMC Martindale-Hubbell, Directories (1955) No. 92-001A F7; 1 THE MARTINDALEHUBBELL LAW DIRECTORY 343, $107^{\text {th }}$ Annual Edition (Martindale-Hubbell, Inc. 1975), microformed on LLMC Martindale-Hubbell, Directories (1975) No. 92-001A F14.

${ }^{17}$ See, e.g., Wilson v. Commissioner of Internal Revenue, 14 T.C.M. (CCH) 299 (1955); Cole v. Commissioner of Internal Revenue, 13 T.C.M. (CCH) 1135 (1954); Hutchins v. Commissioner of Internal Revenue, 8 T.C.M. (CCH) 809 (1949); Dean v. Davis, 166 P.2d 15 (Cal. Dist. Ct. App. 1946).

${ }^{18}$ Mrs. Fields Called "Vulture" in Letter, L.A. TIMES, May 6, 1949, at 2.

${ }^{19}$ Burns-Allen Tax Plea Filed, L.A. TIMES, Dec. 15 1938 , at 1.

${ }^{20}$ Mrs. Fields Called "Vulture" in Letter.

${ }^{21}$ Coburn and His Poker-Playing Friends Fined, L.A. TIMES, June 14, 1951, at A1.

${ }^{22} 1$ THE MARTINDALE-HUBBELL LAW DIRECTORY $385,116^{\text {th }}$ Annual Edition (Martindale-Hubbell, Inc. 1984), microformed on LLMC Martindale-Hubbell, Directories (1984) No. 92-001A F7; Social Security
Death Index (Lexis Advance, Public Records, Death Records).

${ }^{23}$ Area Briefs:UND's Zierdt Gets Law Professorship, GRAND FORKS (N.D.) HERALD, Nov. 28, 2001, 2001 WLNR 2295318.

${ }^{24}$ Kirkham Oral History at 11-12. See also Francis Robison Kirkham, THE COMPLETE MARQUIS WHO'S WHO (Marquis Who's Who 2001); Supreme Court Library Correspondence.

${ }^{25}$ Kirkham Oral History at viii, 1-2, 98-101; Francis Robison Kirkham, THE COMPLETE MARQUIS WHO'S WHO; Francis R. Kirkham, SAN FRANCISCO CHRONICLE, Oct. 26, 1996, p. A20; Death: Francis $R$. Kirkham, DESERET NEWS, Oct. 27, 1996, p. 11.

${ }^{26}$ Kirkham Oral History at 3-7.

${ }^{27}$ Kirkham Oral History at iii, 11-12; Francis Robison Kirkham, THE COMPLETE MARQUIS WHO'S WHO; Francis R. Kirkham, SAN FRANCISCO CHRONICLE, Death: Francis R. Kirkham, DESERET NEWS.

${ }^{28} 287$ U.S. 45 (1932).

${ }^{29} 290$ U.S. 398 (1934).

${ }^{30}$ Kirkham Oral History at $12-14$.

${ }^{31}$ Kirkham Oral History at 14-16, 23.

${ }^{32}$ Kirkham Oral History at 7-9; Francis Robison Kirkham, THE COMPLETE MARQUIS WHO'S WHO; Francis R. Kirkham, SAN FRANCISCO CHRONICLE; Death: Francis R. Kirkham, DESERET NEWS.

${ }^{33}$ After his interview with McReynolds, Musser wrote to Kirkham, "Sutherland's immediate recommendation vital. Please arrange this. Will count on it." Telegram from Milton S. Musser to Francis R. Kirkham, March 24, 1938, Box 23, Folder 1, Milton Shipp Musser MSS, Utah State Historical Society. Musser also listed Kirkham as a reference on the resume he submitted to McReynolds following the interview. See Musser to McReynolds, April 16, 1938, Box 23, Folder 1, Musser MSS. For more detail on Kirkham's role in the events leading up to McReynolds' hiring of Musser, see Clare Cushman, "Beyond Knox: James C. McReynolds' Other Law Clerks, 1914-1941," in Clare Cushman and Todd Peppers, eds., OF COURTIERS AND KINGS: STORIES OF SUPREME COURT LAW CLERKS AND THEIR JUSTICES (UVA Press, forthcoming).

${ }^{34}$ Kirkham Oral History at vi, 16-19, 23; Francis Robison Kirkham, THE COMPLETE MARQUIS WHO'S WHO; Francis R. Kirkham, SAN FRANCISCO CHRONICLE; Death: Francis R. Kirkham, DESERET NEWS; Hearings Before the Subcommittee on Multinational Corporations of the Committee on Foreign Relations, 93d Cong. 405 (1974) (statements by Francis R. Kirkham, cited as General Counsel to Standard Oil Co. of California).

${ }^{35}$ See, e.g., Western Union Tel. Co. v. Nester, 309 U.S. 582 (1940); Lehv. General Petroleum Corp., 382 U.S. 54 (1965); United States $v$. Leiter Minerals, Inc., 381 U.S. 
413 (1965); City of San Francisco v. Skelly Oil Co., 389 U.S. 817 (1967); Perkins v. Standard Oil Co. of California, 393 U.S. 1013 (1969); Hawaii v. Standard Oil Co. of California, 405 U.S. 251 (1972).

${ }^{36}$ Kirkham Oral History at v-vi, 16, 23-24, 122-24; Francis Robison Kirkham, THE COMPLETE MARQUIS WHO'S WHO; Francis R. Kirkham, S.F. CHRONICLE; Death: Francis R. Kirkham, DESERET NEWS. See also Francis R. Kirkham, et al., Colloquy on Complex Litigation, 1981 B.Y.U. L. REV. 741; Francis R. Kirkham, Problems of Complex Civil Litigation, 83 F.R.D. 497 (1979); Francis R. Kirkham, Complex Civil Litigation Have Good Intentions Gone Awry?, 70 F.R.D. 199 (1976); Reuben G. Hunt, Arrangements Under Chapter XI of Bankruptcy Act, 1939 Sec. Comm. L. 21, 22 (1939).

${ }^{37}$ Kirkham Oral History at 125; Francis Robison Kirkham, THE COMPLETE MARQUIS WHO'S WHO; Francis R. Kirkham, S.F. CHRONICLE; Death: Francis $R$. Kirkham, DESERET NEWS.

${ }^{38}$ Wallace Kaapcke, "General Civil Practice: A Varied and Exciting Life at Pillsbury, Madison and Sutro," an oral history conducted $1986-1987$ by Carole Hicke, Regional Oral History Office, The Bancroft Library, University of California at Berkeley 21, 310 (1990).

39 "I had a long association with him and I enjoyed every bit of it. I enjoyed it intellectually and enjoyed it personally. And I stress both, because sometimes you can enjoy people personally that maybe you don't enjoy intellectually and vice versa, but Mr. Kirkham is one of the outstanding lawyers that I've ever had any contact with in combining those two qualities." Turner $\mathrm{H}$. McBaine, "A Career in the Law at Home and Abroad," an oral history conducted 1986 by Carole Hicke, Regional Oral History Office, The Bancroft Library, University of California at Berkeley 69-70 (1989).

${ }^{40}$ Wallace Kaapcke, "General Civil Practice: A Varied and Exciting Life at Pillsbury, Madison and Sutro," an oral history conducted $1986-1987$ by Carole Hicke, Regional Oral History Office, The Bancroft Library, University of California at Berkeley 21 (1990).

${ }^{41} I d$. at 248. "The summation of what I learned from Francis Kirkham was the importance of always doing it right. Taking every care that you had to take to be sure that your conclusion, your action, your contract, your document, your brief, your pleading, whatever it was, was done right. I think I've had a lifetime course at the feet of Francis Kirkham in always doing it right. I want to express my thanks to him for that and also for a lifetime of professional and personal friendship." Id. at 311.

${ }^{42}$ Kirkham Oral History at vii.

43 John Bates, "Litigation and Law Firm Management at Pillsbury, Madison and Sutro," an oral history conducted 1986 by Carole Hicke, Regional Oral History Office, The Bancroft Library, University of California at Berkeley 202-03 (1988). Explaining why Kirkham did not serve on the firm's management committee, Bates stated, "I think the senior partners felt that Francis Kirkham was so valuable to the total profession, really a genius in the practice of law, that they didn't want to impose on him to bother with the management of the affairs of the firm. They were quite happy to give him top recognition and distributions and all that sort of thing, but they didn't want to burden him with the day-to-day management of the affairs of the firm." Id. at 204. See also Charles F. Prael, "Litigation and the Practice of Labor Law at Pillsbury, Madison and Sutro, 1934-1977," an oral history conducted 1985 by Carole Hicke, Regional Oral History Office, The Bancroft Library, University of California at Berkeley 26 (1986) (Kirkham "contributed tremendously to the standing of the firm").

44 Turner H. McBaine, "A Career in the Law at Home and Abroad," an oral history conducted 1986 by Carole Hicke, Regional Oral History Office, The Bancroft Library, University of California at Berkeley 77 (1989). 45 James O'Brien, "Odyssey of a Journeyman Lawyer," an oral history conducted 1987-1989 by Carole Hicke, Regional Oral History Office, The Bancroft Library, University of California at Berkeley 210 (1991). See also id. at 194-96 on Kirkham's talents as a lawyer.

${ }^{46}$ Kirkham Oral History at ii-viii.

${ }^{47}$ Supreme Court Library Correspondence.

${ }^{48}$ Employment Record of John W. Cragun, National Personnel Records Center, National Archives at St. Louis (on file with the author); 5 WHO WAS WHO IN AMERICA 156 (1973); Indian Claims Commission Files of Wilkinson, Cragun, \& Barker, ca. 1950-1982, Brigham Young University, http://files.lib.byu.edu/ead/ XML/MSS2291.xml

${ }^{49} 5$ WHO WAS WHO IN AMERICA 156 (1973); Robert W. Barker, Memorial to John Wiley Cragun Presented to the United States Court of Claims, May 6, 1969, 21 ADMIN. L. REV. xvii (1969).

${ }^{50}$ Barker at xvii.

${ }^{51} 5$ WHO WAS WHO IN AMERICA 156 (1973); Barker at xvii.

${ }^{52}$ Indian Claims Commission Files of Wilkinson, Cragun, \& Barker, ca. 1950-1982, Brigham Young University, http://files.lib.byu.edu/ead/XML/MSS2291. xml. See, e.g., Pierce Estates, Inc. v. Commissioner, 16 T.C. 1020 (1951); Barker at xvii.

535 WHO WAS WHO IN AMERICA 156 (1973); Indian Claims Commission Files of Wilkinson, Cragun, \& Barker, ca. 1950-1982, Brigham Young University, http://files.lib. byu.edu/ead/XML/MSS2291.xml; Barker at xvii.

545 WHO WAS WHO IN AMERICA 156 (1973); Barker at xviii, xix. See, e.g., Federal Power Commission v. Southern California Edison Co., 376 U.S. 205 (1964); Menominee Tribe v. United States, 391 U.S. 404 (1968); Kake Village v. Egan, 369 U.S. 60 (1962); Squire v. Capoeman, 351 U.S. 1 (1956); Dodge, Superintendent of 
the Osage Indian Agency v. United States, 362 F. 2 d 810 (Ct. Cl. 1966); Big Eagle v. United States, 300 F. 2d 765 (Ct. Cl. 1962); Upper Skagit Tribe of Indians v. United States, 20 Ind. Cl. Comm. 381 (1969), http://digital. library.okstate.edu/icc/v20/iccv20p381.pdf; Northern Cheyenne Indians of the Tongue River, Montana v. United States, 13 Ind. Cl. Comm. 1 (1963), http://digital.library. okstate.edu/icc/v13/iccv13p001.pdf. See generally Indian Claims Commission Files of Wilkinson, Cragun, \& Barker, ca. 1950-1982, Brigham Young University, http://files.lib.byu.edu/ead/XML/MSS2291.xml ${ }^{55}$ Barker at xviii.

${ }^{56} 5$ WHO WAS WHO IN AMERICA 156 (1973); Barker at xvii-xviii; Robert M. Benjamin, A Lawyer's View of Administrative Procedure - The American Bar Association Program, 26 LAW \& CONTEMP. PROBS. 203, 206 n.14 (1961); John W. Cragun, Who Is the Judge, Agency or Court?, 13 WYO. L.J. 111 (1958); John W. Cragun, Admission to Practice: Present Regulation by Federal Agencies, 34 A.B.A. J. 111 (1948).

${ }^{57} 5$ WHO WAS WHO IN AMERICA 156 (1973); Barker at $\mathrm{xx}$.

${ }^{58}$ Chester A. Newland, Personal Assistants to the Supreme Court Justices: The Law Clerks, 40 ORE. L. REV. at 303, 307, 308, 312 (1961); Norman Dorsen, Law Clerks in Appellate Courts in the United States, 26 MODERN LAW REVIEW 265, 265 (1963); David Schroeder, "More Than a Fraction, The Life and Work of Justice Pierce Butler" (unpublished Ph.D. dissertation, Marquette University, 2009) at 166-67; John G. Kester, The Law Clerk Explosion, 9 LITIGATION 20, 22 (1983). See also correspondence from the Supreme Court of the United States Library dated June 26, 2002 (hereinafter Supreme Court Library Correspondence). While there is no complete list of all Supreme Court law clerks, the Library maintains unofficial internal files relating to clerks' service at the Court, which it recognizes may contain incomplete and unverified information.

${ }^{59}$ Cotter Employment Record.

${ }^{60} 1$ THE MARTINDALE-HUBBELL LAW DIRECTORY 403, $88^{\text {th }}$ Annual Edition (Martindale-Hubbell, Inc. 1956), microformed on LLMC Martindale-Hubbell, Directories (1956) No. 92-001 A F20. See also Supreme Court Library Correspondence; Schroeder, "More Than a Fraction," at 166.

${ }^{61}$ Schroeder at $166-67$.

${ }^{62}$ Id. at 166; Employment Record of John Francis Cotter, National Personnel Records Center, Valmeyer, Illinois, on file with the author (hereinafter "Cotter Employment Record").

${ }^{63}$ Id. at 166; Cotter Employment Record.

${ }^{64}$ Id. at 4, 82 n.197, 167.

${ }^{65}$ Cotter Employment Record.

${ }^{66}$ See, e.g., U.S. v. Fixico, 115 F. 2 d $389\left(10^{\text {th }}\right.$ Cir. 1940); U.S. v. Tilley, 124 F. 2 d $850\left(8^{\text {th }}\right.$ Cir. 1941); U.S. v.
Foster, 131 F.2d 3 ( $8^{\text {th }}$ Cir. 1942); U.S. v. Waterhouse, 132 F. 2d 699 ( $9^{\text {th }}$ Cir. 1943); Sioux Tribe of Indians $v$. United States, 329 U.S. 684 (1946); Arenas v. U.S., 331 U.S. 842 (1947); U.S. v. Woodworth, 170 F.2d 1019 (2d Cir. 1948); U.S. v. Hayes, 172 F.2d 677 (9 $9^{\text {th }}$ Cir. 1949); City of Fort Worth v. U.S., 185 F.2d 397 ( $5^{\text {th }}$ Cir. 1950); U.S. v. Marks, 187 F.2d 784 ( $9^{\text {th }}$ Cir. 1951); Title Ins. \& Guar. Co. v. United States, 194 F.2d 916 ( $9^{\text {th }}$ Cir. 1952); United States v. Catlin, 204 F.2d 661, $662\left(7^{\text {th }}\right.$ Cir. 1953); United States v. South Dakota, 212 F.2d $14\left(8^{\text {th }}\right.$ Cir. 1954); Werner v. United States, 233 F.2d 52, $53\left(9^{\text {th }}\right.$ Cir. 1956).

${ }^{67}$ AncestryLibrary.com, U.S. World War II Army Enlistment Records, 1938-1946 Cotter Employment Record.

${ }^{68}$ Cotter Employment Record.

${ }^{69}$ See, e.g., 1 THE MARTINDALE-HUBBELL LAW DIRECTORY $365,89^{\text {th }}$ Annual Edition (MartindaleHubbell, Inc. 1957), microformed on LLMC MartindaleHubbell, Directories (1957) No. 92-001A F19; 1 THE MARTINDALE-HUBBELL LAW DIRECTORY 592, 97 ${ }^{\text {th }}$ Annual Edition (Martindale-Hubbell, Inc. 1965), microformed on LLMC Martindale-Hubbell, Directories (1965) No. 92-001A F27; 1 THE MARTINDALEHUBBELL LAW DIRECTORY 945, $107^{\text {th }}$ Annual Edition (Martindale-Hubbell, Inc. 1975), microformed on LLMC Martindale-Hubbell, Directories (1975) No. 92-001A F47.

${ }^{70}$ Ancestry.com, U.S. Social Security Death Index, 1935-Current.

${ }^{71}$ Supreme Court Library Correspondence.

${ }^{72}$ Letter from Christopher J. Doby, Financial Clerk, United States Senate, to the author, March 20, 2014 (on file with the author); S. Doc. No. 158, at 14 (1919) (Report of the Secretary).

${ }^{73}$ What the Big Fraternal Orders Are Doing, WASH. POST, Mar. 21, 1920, p. 57.

${ }^{74}$ Georgetown Alumni Directory, 1947 Tablet Unveiled for Hilltop Boys Who Died in the War, WASHINGTON HERALD, June 15, 1921, p. 2.

${ }^{75}$ Names Asked of Reservists for Schooling: Infantry and Engineer Courses, WASH. POST, Oct. 15, 1933, p. 16. ${ }^{76}$ Mrs. C.A. Dyke Dies Following Holiday Feast, WASH. POST, Dec. 26, 1948, p. M12. Deaths, SO. MED. J., Dec. 1941, p. 1294.

${ }^{77}$ Supreme Court Library Correspondence.

${ }^{78}$ See Norris Darrell, Lawyer and Tax Expert, 90; N.Y. TIMES, Aug. 15, 1989, p. B5; Norris Darrell, NEWSDAY, Aug. 16, 1989, p. 45; WHO'S WHO IN AMERICAN LAW 198 (2d ed.); Norris Darrell, "Some Personal Reminiscences," in "Reminiscences by Alumni Who Graduated Fifty Years or More Ago From the University of Minnesota Law School" 4 (Minneapolis, 1976) (unpublished manuscript on file with the University of Minnesota Law School). 
${ }^{79}$ Norris Darrell, "Some Personal Reminiscences," at 4.

${ }^{80} \mathrm{Id}$. at 5 .

${ }^{81} \mathrm{Id}$. at $5-6$

${ }^{82}$ See Norris Darrell, Lawyer and Tax Expert, 90, N.Y. TIMES, Aug. 15, 1989, p. B5; Norris Darrell, NEWSDAY, Aug. 16, 1989, p. 45; WHO'S WHO IN AMERICAN LAW 198 (2d ed.); NANCY LISAGOR AND FRANK LIPSIUS, A LAW UNTO ITSELF: THE UNTOLD STORY OF THE LAW FIRM SULLIVAN \& CROMWELL 100, 119-20, 130, 203-04 (1988); SULLIVAN \& CROMWELL, 1879-1979: A CENTURY AT LAW 39, 58-60, 64 (1979); Reminiscences of Norris Darrell in WILLIAM PIEL, JR., et al., eds., LAMPLIGHTERS: THE SULLIVAN AND CROMWELL LAWYERS APRIL 2, 1879 TO APRIL 2, 1979 110-17 (1981). Darrell published widely on issues of federal taxation and professional responsibility. See, e.g., Norris Darrell and Paul A. Wolkin, The American Law Institute, 52 N.Y. ST. B.J. 99 (1980); Norris Darrell, Conscience and Propriety in Tax Practice, in THE LAWYER IN MODERN SOCIETY 361, 363 (VERN COUNTRYMAN et al. eds., $2 d$ ed. 1976); Norris Darrell, Reflections on the Federal Income Tax, 28 REC. ASS'N B. CITY N.Y. 412 (1973); Norris Darrell, The Role of Universities in Continuing Professional Education, 32 OHIO ST. L.J. 312 (1971); Norris Darrell, Responsibilities of the Lawyer in Tax Practice, reprinted in PROFESSIONAL RESPONSIBILITY IN FEDERAL TAX PRACTICE 87 (BORIS I. BITTKER, ed., 1970); Norris Darrell, The Tax Lawyer's Duty to His Client and to His Government, 7 PRAC. LAW. 23 (1961); Norris Darrell, Some Challenges of the Legal Profession, 57 BRIEF 8 (1961); Norris Darrell, The Use of Reorganization Techniques in Corporate Acquisitions, 70 HARV. L. REV. 1183 (1957); Norris Darrell, Responsibilities of the Lawyer in Tax Practice, in WILLIAM M. TRUMBULL, ed., MATERIALS ON THE LAWYER'S PROFESSIONAL RESPONSIBILITY 291 (1957); Norris Darrell, Internal Revenue Code of 1954--A Striking Example of the Legislative Process in Action, in MAJOR TAX PROBLEMS OF 19551 (JOHN W. ERVIN, ed., 1955); Norris Darrell, The 1954 Internal Revenue Code - One Year Later: A General Review, 8 TAX EXEC. 23 (1955); Norris Darrell, The Tax Treatment of Payments Under Section I6(B) of the Securities Exchange Act of 1934, 64 HARV. L. REV. 80 (1950); Norris Darrell, Recent Developments in Nontaxable Reorganizations and Stock Dividends, 61 HARV. L. REV. 958 (1948); Norris Darrell, The Scope of Commissioner, 24 TAXES 266 (1946); Norris Darrell, Creditors' Reorganizations and the Federal Income Tax, 57 HARV. L. REV. 1009 (1944); Norris Darrell, Corporate Liquidations and the Federal Income Tax, 89 U. PA. L. REV. 907 (1941); Norris Darrell, Discharge of Indebtedness and the Federal Income Tax, 53 HARV. L. REV. 977 (1940).
He was also a frequent public speaker on these issues. See, e.g., Further Revisions Seen in U.S. Income Tax Laws, L.A. TIMES, Oct. 21, 1954, p. 36; Douglas, Bradford Listed as Speakers in Harvard Law Series, DAILY BOSTON GLOBE, Dec. 9, 1951, p. C24; Display Ad 190 - No Title, N.Y. TIMES, Oct. 7, 1946, p. 35; Events Today, N.Y. TIMES, Apr. 27, 1944, p. 21.

${ }^{83}$ See Norris Darrell, Lawyer and Tax Expert, 90, N.Y. TIMES, Aug. 15, 1989, p. B5; Norris Darrell, NEWSDAY, Aug. 16, 1989, p. 45; Norris Darrell Takes Bride, WASH. POST, June 29, 1945, p. 12; Reminiscences of Norris Darrell, in PIEL, JR., et al. at 116-17. Hand had kinder things to say about Butler at the Justice's death. See Richard J. Purcell, Mr. Justice Pierce Butler (18661939), 10 THE RECORDER 33, 36 (May 1, 1940).

${ }^{84}$ Reminiscences of Norris Darrell, in PIEL, JR., et al. at 116-17; Gerald Gunther, " Contracted' Biographies and Other Obstacles to 'Truth,", 70 N.Y.U. L. REV. 697 (1995); GERALD GUNTHER, LEARNED HAND: THE MAN AND THE JUDGE xix (1994); David Margolick, In the Mentor's Steps: Law Professor Tries to Capture Professional, Personal Aspects of Jurist Learned Hand, DALLAS MORNING NEWS, May 8, 1994, p. 8A.

${ }^{85} 17$ Leading Lawyers Call Civil Rights Bill Constitutional, N.Y. TIMES, Sept. 19, 1966, p. 37.

${ }^{86}$ See Norris Darrell, Lawyer and Tax Expert, 90, N.Y TIMES, Aug. 15, 1989, p. B5; Norris Darrell, NEWSDAY, Aug. 16, 1989, p. 45.

${ }^{87}$ Supreme Court Library Correspondence.

${ }^{88} 1$ THE MARTINDALE-HUBBELL LAW DIRECTORY $11406,67^{\text {th }}$ Annual Edition (Martindale-Hubbell, Inc. 1935), microformed on LLMC Martindale-Hubbell, Directories (1935) No. 92-001A F4.

891932 J. SUP. CT. U.S. 47 (1932); U.S. v. Stephanidis, 47 F.2d 554 (2d Cir. 1931).

${ }^{90}$ ANNUAL MEETING, THE MARITIME LAW ASSOCIATION OF THE UNITED STATES, APRIL 26, 1935 (Document No. 207, April, 1935), p. 2135; The Santa Lucia, 44 F. Supp. 793 (D.C.N.Y. 1942); Public Warehouses of Matanzas, Inc. v. Fidelity \& Deposit Co. of Maryland, 77 F.2d 831 (2d Cir. 1935); Lloyd Royal Belge Societe Anonyme v. Elting, 289 U.S. 730 (1933); St. Paul Fire \& Marine Ins. Co. v. Pure Oil Co., 63 F.2d 771 (2d Cir. 1933), 81 Ins. L.J. 315 (1933); Earl \& Stoddart, Inc., v. Elderman's Wilson Line, Ltd., 287 U.S 420, 423 (1932); Prince Line v. American Paper Exports, Inc., 55 F.2d 1053 (2d Cir. 1932); The Pasadena, 55 F.2d 51 ( $4^{\text {th }}$ Cir. 1932).

${ }^{91}$ Bar Adds Notables to Its Committees, N.Y. TIMES, Jul. 12, 1933, p. 34; Bar Committees Chosen for Year, N.Y. TIMES, Jul. 10, 1936, p. 10.

${ }^{92}$ See, e.g., 1 THE MARTINDALE-HUBBELL LAW DIRECTORY $11406,67^{\text {th }}$ Anmual Edition (MartindaleHubbell, Inc. 1935), microformed on LLMC Martindale- 
Hubbell, Directories (1935) No. 92-001A F4; 1 THE MARTINDALE-HUBBELL LAW DIRECTORY 1452 , $77^{\text {th }}$ Annual Edition (Martindale-Hubbell, Inc. 1945), microformed on LLMC Martindale-Hubbell, Directories (1945) No. 92-001A F49; 2 THE MARTINDALEHUBBELL LAW DIRECTORY $1530,85^{\text {th }}$ Annual Edition (Martindale-Hubbell, Inc. 1953), microformed on LLMC Martindale-Hubbell, Directories (1953) No. 92-001A F67.

${ }^{93}$ Richard L. Sullivan, AncestryLibrary.com.

${ }^{94}$ PEPPERS at 93

${ }^{95}$ Employment Record of William D. Donnelly, National Personnel Records Center, National Archives at St. Louis (on file with the author); William D. Donnelly, Former D.C. Lawyer, WASH. POST, March 12, 1975, p. C6. See, e.g., U.S. v. Price, 111 F. $2 \mathrm{~d} 206\left(10^{\text {th }}\right.$ Cir. 1940$)$; U.S. v. Harris, $\left(9^{\text {th }}\right.$ Cir. 1939); City of Springfield v. U.S., 99 F.2d 860 ( $1^{\text {st }}$ Cir. 1938). In August of 1937 Donnelly applied to serve as Justice Black's clerk. PEPPERS at 93. ${ }^{96}$ William D. Donnelly, Former D.C. Lawyer, WASH. POST, March 12, 1975, p. C6. See, e.g., Decker v. U.S., 140 F.2d $375\left(4^{\text {th }}\right.$ Cir. 1944); Douglas Aircraft Co.v. U.S., 95 Ct. Cl. 140 (1941).

${ }^{97}$ See Homer Stille Cummings Papers, Special Collections, University of Virginia, Series III, V, \& VI.

${ }^{98}$ See Boxes 323, 325, and 327, Cummings Papers.

${ }^{99}$ Attorney Ends Testimony in Johnson Probe, CHI. TRIB., Apr. 24, 1946, p. 8; Johnson Legal Aid Denounces U.S. Jury's Quiz, CHI. TRIB., Apr. 23, 1946, p. 20.

${ }^{100} 1938$ J. SUP. CT. U.S. 127 (1939).

${ }^{101}$ See, e.g., Girouard v. U.S., 328 U.S. 61 (1946); Herget v. Central Nat. Bank \& Trust Co. of Peoria, 324 U.S. 4 (1945); Chrysler Corp. v. U.S., 316 U.S. 556 (1942); Glasser v. U.S., 315 U.S. 60 (1942). See also, e.g., Diaz v. Southeastern Drilling Corp. of Argentina, S.A., 449 F.2d 258 ( $5^{\text {th }}$ Cir. 1971); Cap Santa Vue, Inc. v. NLRB, 424 F.2d 883 (D.C. Cir. 1970); Rossi v. Fletcher, 418 F.2d 1169 (D.C. Cir. 1969); Schleit v. British Overseas Airways Corp., 410 F.2d 261 (D.C. Cir. 1969); Vinson v. Rexrode, 404 F.2d 830 (D.C. Cir. 1968); Wheaton Triangle Lanes, Inc. v. Rinaldi, $236 \mathrm{Md}$. 525 (1964); Trent Trust Co. v. Kennedy, 307 F.2d 174 (D.C. Cir. 1962).

102374 U.S. 398 (1963); 50 A.B.A. J. 82 (1964).

${ }^{103}$ Solicitors' Ordinance Draws Fire, WASH. POST, Oct. 28,1953 , p. 32 . Donnelly also represented the Seventh-Day Adventist Welfare Service, Inc. in Orient Mid-East Lines, Inc., v. Cooperative for Am. Relief Everywhere, Inc., 410 F.2d 1006 (D.C. Cir. 1969), and the General Conference in Town of Green River v. Martin, 71 Wyo. 81 (1953).

${ }^{104}$ See, e.g., Orient Mid-East Lines, Inc., v. Cooperative for Am. Relief Everywhere, Inc., 410 F.2d 1006 (D.C. Cir.
1969); Gallagher v. Crown Kosher Market, 366 U.S. 617,618 (1961); Town of Green Riverv. Martin, 71 Wyo. 81 (1953). Donnelly also filed an amicus brief on behalf of his church in McCullom v. Board of Education, 333 U.S. 203 (1948). The Church had the firm on retainer, and also asked Donnelly and Cummings to file an amicus brief in Everson v. Board of Education, 330 U.S. 1 (1947). Before this request was made, however, Cummings was approached about the matter by an acquaintance taking the opposing position. Cummings was embarrassed by the conflict, and asked both parties to seek other representation. William H. Speer to Homer Cummings, June 10, 1946, Homer Cummings to William D. Donnelly, June 12, 1946, William D. Donnelly to Homer Cummings, June 20, 1946, Homer Cummings to William H. Speer, June 21, 1946, William D. Donnelly to Homer Cummings, August 10, 1946, Homer Cummings to William H. Speer, August 16, 1946, William H. Speer to Homer Cummings, August 22, 1946, Box 323, Cummings MSS.

${ }^{105} 101$ CONG. REC. D271 (1955); Hearing on S. 18, S. 57, S. 274, S. 662, S. 1288, S. 1437 and S. 1447 Before the Senate Subcommittee on Labor of the Committee on Labor and Public Welfare, 84th Cong. 1156 (1955) (hearings on proposed minimum wage legislation, testimony of William D. Donnelly).

${ }^{106}$ Hearing on H.R.J. Res. 693 Before the H. Comm. on the Judiciary, 88th Cong. 2483-85 (1964).

${ }^{107}$ Cummings \& Stanley Partnership Agreement, January 1,1945 , Box 258, Cummings MSS.

${ }^{108}$ See, e.g., 1 THE MARTINDALE-HUBBELL LAW DIRECTORY 348, 82 ${ }^{\text {nd }}$ Annual Edition (MartindaleHubbell, Inc. 1950), microformed on LLMC MartindaleHubbell, Directories (1950) No. 92-001A F19; 1 THE MARTINDALE-HUBBELL LAW DIRECTORY 219 , $87^{\text {th }}$ Annual Edition (Martindale-Hubbell, Inc. 1955), microformed on LLMC Martindale-Hubbell, Directories (1955) No. 92-001A F14.

${ }^{109} 1$ THE MARTINDALE-HUBBELL LAW DIRECTORY 219, $88^{\text {th }}$ Annual Edition (Martindale-Hubbell, Inc. 1956), microformed on LLMC Martindale-Hubbell, Directories (1956) No. 92-001A F14.

${ }^{110} 1$ THE MARTINDALE-HUBBELL LAW DIRECTORY 630, $98^{\text {th }}$ Annual Edition (Martindale-Hubbell, Inc. 1966), microformed on LLMC Martindale-Hubbell, Directories (1966) No. 92-001A F29.

${ }^{111} 1$ THE MARTINDALE-HUBBELL LAW DIRECTORY 952, $107^{\text {th }}$ Annual Edition (Martindale-Hubbell, Inc. 1975), microformed on LLMC Martindale-Hubbell, Directories (1975) No. 92-001A F47.

${ }^{112}$ See 29 J. B. ASSN. D.C. 544 (1962); 28 J. B. ASSN. D.C. 528 (1961); 26 J. B. ASSN. D.C. 399 (1959); 25 J. B. ASSN. D.C. 487 (1958); 23 J. B. ASSN. D.C. 558 (1956); 22 J. B. ASSN. D.C. 483 (1955); 21 J. B. ASSN. D.C. 415, 536 (1954); District 
Barristers Hear about Flotsam, Jetsam and Ligan at $70^{\text {th }}$ Annual Dinner, WASH. POST, Dec. 7, 1941, p. 14.

11327 J. B. ASSN. D.C. 483 (1960); 26 J. B. ASSN. D.C. 399 (1959); 23 J. B. ASSN. D.C. 557-58 (1956); 21 J. B. ASSN. D.C. 536 (1954); 16 J.B. ASSN. D.C. 231, 582 (1949).

${ }^{114}$ William D. Donnelly, Former D.C. Lawyer, WASH. POST, March 12, 1975, p. C6.

115 Supreme Court Library Correspondence.

${ }^{116}$ Civic Leader Irving Clark Dies at 84; Was St. Paul Law Firm Partner, MINN. STAR TRIB., Jan. 21, 1997, p. $7 \mathrm{~B}$.

${ }^{117}$ See, e.g., Matter of Schroll, 297 N.W.2d 282 (Minn. 1980); Walgreen Co. v. Commissioner of Taxation, 252 Minn. 522 (1960); Cut Price Supermarkets v. Kingpin Foods, Inc., 256 Minn. 339 (1959); U.S. v. Goodson, 253 F.2d 900 ( $8^{\text {th }}$ Cir. 1958); Gilfillan v. Kelm, 128 F. Supp. 291 (D.C. Minn. 1955); Reynolds v. Hill, 184 F.2d 294 ( $8^{\text {th }}$ Cir. 1950); Myers Motors v. Kaiser-Frazer Sales Corp., 178 F. 2d 291 ( $8^{\text {th }}$ Cir. 1950); State v. Peery, 224 Minn. 346 (1947); U.S. v. Northwest Airlines, 69 F. Supp. 482 (D. Minn. 1946). See also Irving Clark \& Eugene M Warlich, Taxation of Cooperatives: A Problem Solved?, 47 MINN. L. REV. 997 (1963).

${ }^{118}$ Civic Leader Irving Clark Dies at 84. See, e.g., Land O'Lakes Co. v. U.S., 675 F. 2d 988 (8th Cir. 1982); Associated Milk Producers, Inc. v. Commissioner, 68 T.C. 729 (1977); Louis W. and Maud Hill Family Foundation v. U.S., 347 F. Supp. 1225 (D.C. Minn. 1972); Farmers Union Co-op Oil Assn. of South St. Paul v. Commissioner of Taxation, 1968 WL 20 (Minn. Tax. Ct. 1968).

${ }^{119}$ Civic Leader Irving Clark Dies at 84; Funeral Notices, ST. PAUL PIONEER PRESS, Jan. 18, 1997, p. B5; Hill Family and Foundation Squabble Over Charity's Future, MINN. STAR TRIB., Jan. 31, 1994, p. 1A; Minnesota Foundations Keep Family Connections, MINN. STAR TRIB., Jan. 31, 1994, p. 6A.

${ }^{120}$ Antipoverty Pioneers Defend Legacy of ' 60 s, MINN. STAR TRIB., May 24, 1992, p. 1 A.

${ }^{121}$ Civic Leader Irving Clark Dies at 84; Funeral Notices, ST. PAUL PIONEER PRESS, Jan. 18, 1997, p. B5.

122 Supreme Court Library Correspondence; Employment Record of Luther E. Jones, Jr., National Personnel Records Center, National Archives at St. Louis (hereinafter "Jones Employment Record") (on file with the author).

${ }^{123}$ ROBERT A. CARO, THE YEARS OF LYNDON JOHNSON: THE PATH TO POWER 230 (1982).

${ }^{124}$ CARO at 207-08.

${ }^{125}$ Interview with Luther E. Jones, Jr., conducted by David McComb, June 13, 1969, Lyndon Baines Johnson Library, 1, 2-4, http://millercenter.org/scripps/archive/ oralhistories/detail/2638 (hereinafter McComb interview); CARO at 207-11; MERLE MILLER, LYNDON: AN ORAL BIOGRAPHY 35 (1980).
${ }^{126}$ McComb interview at 1-2, 5; CARO at 229-30; ROBERT DALLEK, LONE STAR RISING: LYNDON JOHNSON AND HIS TIMES, 1908-1960 100 (1991); ALFRED STEINBERG, SAM JOHNSON'S BOY: A CLOSE-UP OF THE PRESIDENT FROM TEXAS 59 (1968); Jones Employment Record.

${ }^{127}$ RANDALL B. WOOD, LBJ: ARCHITECT OF AMERICAN AMBITION 78 (2006); DALLEK at 100 ${ }^{128}$ DALLEK at 100.

${ }^{129}$ McComb interview at 8; WOOD at 78; DALLEK at 100; CARO at 231; RONNIE DUGGER, THE POLITICIAN: THE LIFE AND TIMES OF LYNDON JOHNSON: THE DRIVE FOR POWER, FROM THE FRONTIER TO MASTER OF THE SENATE 166 (1982).

${ }^{130}$ WOOD at 79

${ }^{131}$ DALLEK at 100 ; WOOD at 79 ; STEINBERG at 77 ; MILLER at 41.

${ }^{132}$ McComb interview at 9; DALLEK at 100.

${ }^{133}$ WOOD at 79; DALLEK at 101; CARO at 232.

${ }^{134}$ DALLEK at 101.

${ }^{135}$ McComb interview at 6; DALLEK at 101; MILLER at 41 ; STEINBERG at 77.

${ }^{136}$ WOOD at 79; CARO at 232.

${ }^{137}$ CARO at 339; DALLEK at 101; WOOD at 79.

${ }^{138}$ DALLEK at 101. See also WOOD at 79.

${ }^{139}$ CARO at 238-39; DALLEK at 101-02; WOOD at 79; IRWIN UNGER \& DEBI UNGER, LBJ: A LIFE 371 (1999).

${ }^{140}$ CARO at 239.

${ }^{141}$ DALLEK at 102. See also CARO at 239; UNGER \& UNGER at 371.

${ }^{142}$ McComb interview at 6; WOOD at 79; DALLEK at 101; MILLER at 41.

${ }^{143}$ DALLEK at 101. See also WOOD at 79.

${ }^{144}$ CARO at 238.

${ }^{145}$ Interview with Luther E. Jones, Jr., conducted by Michael L. Gillette, October 14, 1977, Lyndon Baines Johnson Library, 15, http://millercenter.org/scripps/archive/oralhistories/detail/2639 (hereinafter Gillette interview). See also McComb interview at 29.

${ }^{146}$ DUGGER at 187.

${ }^{147}$ McComb interview at 9; MILLER at 41.

${ }^{148}$ McComb interview at 23; DUGGER at 125.

${ }^{149}$ WOOD at $79-80$.

${ }^{150}$ WOOD at $79-80$; DALLEK at 102 ; UNGER \& UNGER at 44; STEINBERG at 77 . Johnson also frequently wrote to each of the young men's parents to report on their progress. WOOD at 80 .

${ }^{151} \mathrm{McComb}$ interview at 2; Gillette interview at 18-20; WOOD at 90; DUGGER at 179; CARO at 338; UNGER \& UNGER at 44-45.

${ }^{152}$ Gillette interview at 23-24; HAL K. ROTHMAN, LBJ'S TEXAS WHITE HOUSE 28 (2001); DUGGER at 174-75; CARO at 276-77. 
153 DUGGER at 217; CARO at 239.

${ }^{154}$ McComb interview at 2; Gillette interview at 26, 28; CARO at 340-48; PAUL K. CONKIN, BIG DADDY FROM THE PEDERNALES: LYNDON BAINES JOHNSON 75 (1986); WOOD at 114; DUGGER at 186-87; Jones Employment Record.

${ }^{155}$ McComb interview at 16, 20; Gillette interview at 13-15; Jones Employment Record; CARO at 396; CONKIN at 80; DUGGER at 190. Jones reported that it was also decided at that meeting that Johnson would support the Court-packing Plan, to which Wirtz was opposed and about which Johnson simply did not care. The men agreed that Johnson could not win without the Roosevelt vote. Id.; CARO at 396.

${ }^{156}$ McComb interview at 2-3, 19-20; Gillette interview at 35; CARO at $443-44$.

${ }^{157} \mathrm{McC}$ Comb interview at 22; Gillette interview at 37-38; Former Assistant District Attorney Jones Dead at 85; Luther E. Jones Jr. Served Corpus Christi in Various Areas of Legal Practice, Served as Assistant to Federal Agencies, CORPUS CHRISTI CALLER-TIMES, Sept. 9, 1999, p. F6; E-mail from Katherine Logan, CPP, Director of the Office of Payroll and Benefits, U.S. House of Representatives, to the author, April 29, 2014 (on file with the author); DALLEK at 102 . When Jones had left Washington to attend law school in Austin, Johnson had promised him that he would help Jones find a Washington job upon his graduation. Id.; CARO at 239. ${ }^{158} \mathrm{McComb}$ interview at 23; DALLEK at 186.

${ }^{159}$ WOOD at 131; Jones Employment Record. See also Gillette interview at 20-21; McComb interview at 23 ("I became clerk to Justice Butler on the Supreme Court for about thirteen months"). This is the only mention of the Butler clerkship in the Jones oral history. The interviewer made no further inquiry about the clerkship.

${ }^{160} \mathrm{Id}$. at 133 . For Jones's more discursive report of Connally's love affair with his own locks, see MILLER at 40 .

161 Jones Employment Record; McComb interview at 23; Gillette interview at 13; Former Assistant District Attorney Jones Dead at 85; Luther E. Jones Jr. Served Corpus Christi in Various Areas of Legal Practice, Served as Assistant to Federal Agencies, CORPUS CHRISTI CALLER-TIMES, Sept. 9, 1999, p. F6. See, e.g., U.S. v. 2,049.85 Acres of Land, More or Less, in Nueces County, Texas, 49 F. Supp. 20 (S.D. Tex. 1943); U.S. v. 250 Acres of Land, More or Less, in Nueces County, Texas, 43 F. Supp. 937 (S.D. Tex. 1942); U.S. v. 16,572 Acres of Land, More or Less, 45 F. Supp. 23 (S.D. Tex. 1942).

${ }^{162}$ JAKE PICKLE \& PEGGY PICKLE, JAKE 37-38 (1997).

${ }^{163}$ Id.; Lynwood Abram, Congressman Shares Storied Tenure, HOUSTON CHRONTCLE, June 1, 1997, 1997 WLNR 6609922.
164 PICKLE \& PICKLE at 38.

${ }^{165} \mathrm{Id}$.

${ }^{166} \mathrm{Id}$. at $38-39$.

${ }^{167} \mathrm{Id}$. at 39.

${ }^{168}$ McComb interview at 23; Former Assistant District Attomey Jones Dead at 85; Local History: Mayor Makes Hires.

${ }^{169}$ Former Assistant District Attorney Jones Dead at 85; See, e.g., Ex Parte Flores, 452 S.W.2d 443 (Tex. Crim. App. 1970); Gonzalez v. State, 397 S.W.2d 440 (Tex. Crim. App. 1965); Huffmeister v. State, 170 Tex. Crim. 460 (1960); Adame v. State, 162 Tex. Crim. 78 (1955); Niemann v. Zarsky, 233 S.W.2d 930 (Tex. Civ. App. 1950); Wingo v. Seale, 212 S.W.2d 968 (Tex. Civ. App. 1948); Corpus Christi Insurance Man Surrenders on Charge of Selling Note Illegally by Mail, WALL ST. J., Jan. 13, 1964, p. 6.

${ }^{170}$ McComb interview at 22, 24-27; CARO at 239; DALLEK at 337; Josiah M. Daniel, III, LBJ v. Coke Stevenson: Lawyering for Control of the Disputed Texas Democratic Party Senatorial Primary Election of 1948 , 31 REV. LITIG. 1, 42 (2012); Johnson v. Stevenson, 170 F.2d $108\left(5^{\text {th }}\right.$ Cir. 1948); Johnson v. Stevenson, 335 U.S. 801 (1948).

17132 FEB-CHAMPION 39 (2008).

${ }^{172}$ WOOD at 567; ROTHMAN at 186.

${ }^{173}$ Bowmer, TEXAS PARADE, May, 1968, p. 45, quoted in CARO at 237-38, 807.

${ }^{174}$ McComb interview at 27; Johnsons Are Hosts At Reunion, WASH. POST, Sept. 14, 1968, p. E1.

175 Former Assistant District Attorney Jones Dead at 85. See, e.g., Buntion v. State, 444 S.W.2d 304 (Tex. Crim. App. 1969).

${ }^{176}$ Former Assistant District Attorney Jones Dead at 85; Funerals, Obituaries, Deaths: Jones, CORPUS CHRISTI CALLER-TIMES (Sept. 8, 1999), http:// www.caller2.com/1999/september/08/funeralstext.html 177 See, e.g., Moser v. U.S. Steel Corp., 676 S.W.2d 99 (Tex. 1984); Hart v. Sims, 702 F.2d 574 ( $5^{\text {th }}$ Cir. 1983); Atchley v. Greenhill, 517 F.2d $692\left(5^{\text {th }}\right.$ Cir. 1975); Hoover v. Beeto, 439 F.2d 913 ( $5^{\text {th }}$ Cir. 1971); Jim D. Bowmer, Bob Burleson, \& Luther E. Jones, Jr., Aggravated Robbery: Texas Style, 33 BAYLOR L. REV. 947 (1981); Percy Foreman \& Luther E. Jones, Jr., Submitting the Law of Parties in a Texas Prosecution, 33 BAYLOR L. REV. 267 (1981); Luther E. Jones, Jr., Theft: Texas Style, 41 TEXAS B.J. 1062 (1978); Percy Foreman \& Luther E. Jones, Jr., Indictments Under the New Texas Penal Code, 15 HOUS. L. REV. 1 (1977); Luther E. Jones, Jr., Admissibility of Confessions in a State Prosecution, 29 BAYLOR L. REV. 1 (1977); Luther E. Jones, Jr., Criminal Law and Procedure, 27 SW. L.J. 227 (1973); Luther E. Jones, Jr., Translating Recent Supreme Court Decisions Into Courtroom Reality, 19 BAYLOR L. REV. 391 (1967); Luther E. 
Jones, Fruit of the Poisonous Tree, 9 S. TEX. L.J. 17 (1967); Luther E. Jones, Jr. \& Warren Burnett, The New Texas Code of Criminal Procedure, 8 S. TEX. L.J. 16 (1966); Jim D. Bowmer, Bob Burleson, \& Luther E. Jones, Jr., Peace Officers and Texas' New Code of Criminal Procedure, 17 BAYLOR L. REV. 268 (1965); Jim D. Bowmer, Luther E. Jones, Jr. \& John H. Miller, The Charge in Criminal Cases, 12 BAYLOR L. REV. 261 (1960).

${ }^{178}$ CARO at 238.

${ }^{179}$ Former Assistant District Attorney Jones Dead at 85. ${ }^{180}$ BROWN at 92. See also DANELSKI at 181-82; Barry Cushman, The Secret Lives of the Four Horsemen, 83 VA. L. REV. 559, 571-79, 639-42 (1997).

${ }^{181}$ Recollection of Herbert Wechsler in KATIE LOUCHHEIM, THE MAKING OF THE NEW DEAL: THE INSIDERS SPEAK 53 (1983) (Stone "thought Butler was too soft in dealing with criminal matters").

${ }^{182}$ The Honorable Supreme Court, FORTUNE, May, 1936, pp. 79, 180, 182. See also JOHN E. SEMONCHE, CHARTING THE FUTURE: THE SUPREME COURT RESPONDS TO A CHANGING SOCIETY, 1890-1920 249 (1978).

183 JAMES E. BOND, I DISSENT: THE LEGACY OF CHIEF [SIC] JUSTICE JAMES CLARK MCREYNOLDS 5, 116-18, 136 (1992).

${ }^{184}$ Richard J. Purcell, Mr. Justice Pierce Butler, THE CATHOLIC EDUCATIONAL REVIEW (April 1944), at 192; DANELSKI at 8.

${ }^{185}$ BOND at $29-51$.

${ }^{186}$ See JOEL FRANCIS PASCHAL, MR. JUSTICE SUTHERLAND: A MAN AGAINST THE STATE 11517, 233 (1951); Jay S. Bybee, George Suthlerland, in
CLARE CUSHMAN, ed., THE SUPREME COURT JUSTICES: ILLUSTRATED BIOGRAPHIES 17892012, 316-17 (3d ed. 2012); Schroeder, "More Than a Fraction," at 79, 128, 150-51, 153, 180, 234; DREW PEARSON \& ROBERT S. ALLEN, THE NINE OLD MEN 41, 159, 198-201 (1936).

${ }^{187} \mathrm{See}$ JEROLD S. AUERBACH, UNEQUAL JUSTICE: LAWYERS AND SOCIAL CHANGE IN MODERN AMERICA 221-29 (1976).

${ }^{188}$ Van Devanter served as the city attorney of Cheyenne in the mid-1880s, as a member of the Wyoming territorial legislature in the late $1880 \mathrm{~s}$, as chief judge of the Wyoming Territorial Supreme Court and of the Wyoming State Supreme Court in 1889 and 1890, as Assistant Attorney General in the Department of the Interior from 1897-1903, as a judge on the United States Court of Appeals for the Eighth Circuit from 1903-10, and on the Supreme Court from 191137. David Burner, Willis Van Devanter, in 3 LEON FRIEDMAN \& FRED L. ISRAEL, eds., THE JUSTICES OF THE UNITED STATES SUPREME COURT: THEIR LIVES AND MAJOR OPINIONS 968-77 (1997). McReynolds was Assistant Attorney General from 1903-06, Special Assistant to the Attorney General from 1907-12, and Attorney General in 1913 and 1914 before serving on the Court from 1914 to 1941. BOND at 27-51. Sutherland was a member of the Utah legislature from 1896-1900, a Congressman from 1901-03, and a United States Senator from 1905-17 before serving on the Court from 1922-38. PASCHAL at 36-98.

${ }^{189}$ See PASCHAL.

${ }^{190}$ See Barry Cushman, The Four Horsemen in Historical Memory (forthcoming). 